\title{
Gene Expression and miRNAs Profiling: Function and Regulation in Human Epidermal Growth Factor Receptor 2 (HER2)-Positive Breast Cancer
}

\author{
Rasha M. Sareyeldin ${ }^{1,2}$, Ishita Gupta ${ }^{1,2}$, Israa Al-Hashimi ${ }^{1,2}$, Hamda A. Al-Thawadi ${ }^{1}$, \\ Halema F. Al Farsi ${ }^{1}$, Semir Vranic ${ }^{1, *(\mathbb{D})}$ and Ala-Eddin Al Moustafa $1,2, *$ (D) \\ 1 College of Medicine, Qatar University, Doha 2713, Qatar; rasha.sareyeldin@gmail.com (R.M.S.); \\ ishugupta28@gmail.com (I.G.); ia1507081@student.qu.edu.qa (I.A.-H.); halthawadi@qu.edu.qa (H.A.A.-T.); \\ halfarsi@qu.edu.qa (H.F.A.F.) \\ 2 Biomedical Research Centre, Qatar University, Doha 2713, Qatar \\ * Correspondence: svranic@qu.edu.qa or semir.vranic@gmail.com (S.V.); aalmoustafa@qu.edu.qa (A.-E.A.M.)
}

Received: 26 April 2019; Accepted: 8 May 2019; Published: 10 May 2019

Abstract: Breast cancer is the second most common cause of cancer-related deaths among women worldwide. It is a heterogeneous disease with four major molecular subtypes. One of the subtypes, human epidermal growth factor receptor 2 (HER2)-enriched (HER2-positive) is characterized by the absence of estrogen and progesterone receptors and overexpression of HER2 receptor, and accounts for $15-20 \%$ of all breast cancers. Despite the anti-HER2 and cytotoxic chemotherapy, HER2 subtype is an aggressive disease with significant mortality. Recent advances in molecular biology techniques, including gene expression profiling, proteomics, and microRNA analysis, have been extensively used to explore the underlying mechanisms behind human breast carcinogenesis and metastasis including HER2-positive breast cancer, paving the way for developing new targeted therapies. This review focuses on recent advances on gene expression and miRNA status in HER2-positive breast cancer.

Keywords: breast cancer; HER2-positive breast cancer; biomarkers; microarray; gene expression profiling; miRNAs

\section{Introduction}

Breast cancer is the most common type of cancer diagnosed in women worldwide with around 2.1 million new cases in 2018 according the World Health Organization. Breast cancer is the leading cause of mortality among women in the majority of countries worldwide [1], metastasis being the leading cause of death [2].

Although early detection of the disease through screening programs, education, and availability of therapeutic agents (chemotherapy, radiation, and targeted treatment) have led to an overall improvement, the survival rates are drastically reduced in 20-30\% of patients who develop metastases. Metastatic breast cancer still represents an incurable disease with a poor outcome, as the median survival is 2-4 years depending on the breast cancer subtype [3].

Several risk factors can be identified at the onset of breast cancer including age at menarche [4], null parity [5], postmenopausal obesity [6], late menopause, high hormonal levels including estradiol, prolactin, and insulin-like growth factor $[7,8]$.

A recent study has shown that breast cancer heterogeneity extends beyond the histopathological classification; however, patients with breast cancer are still grouped according to clinicopathological criteria in order to decide the appropriate therapy and predict their prognosis. These criteria include patient age, tumor size, histological grade as well as the presence or absence of lymph nodes and 
distant metastases, in addition to hormone receptor, estrogen (ER), progesterone (PR) and human epidermal growth factor receptor 2 (HER2) status [9]. Although this has successfully led to decreasing mortality rates over the last three decades, it failed to predict the outcome in different patients, as patients with the same tumor features may have completely different outcomes [9] while other patients suffer from significant toxic side effects [10]. Thus, accurate stratification of breast cancers into clinically related subtypes is of major importance for therapeutic decision making [11].

The availability of high-throughput technology for gene expression profiling, such as microarray, quantitative, and differential-display reverse transcription polymerase chain reaction (RT-PCR), as well as next generation sequencing, have shown that tumor cells respond differently to treatment which is not resolved by clinicopathological aspects, rather by intrinsic molecular features that can be explored using molecular technology [12]. Gene expression (mRNA) profiling studies have allowed intrinsic classification of breast cancer into five main subtypes: Luminal A (ER+/PR+/HER2-) are usually of low grade, luminal $\mathrm{B}(\mathrm{ER}+/ \mathrm{PR}-/+/ \mathrm{HER} 2+/-)$ are generally of higher grade with higher proliferation rate, normal-like subtype that resembles normal breast tissue and is associated with good prognosis, triple-negative breast cancer (ER-/PR-/HER2-), and HER2-enriched subtype (ER-/PR-/HER2+) [13-15]. On the other hand, miRNA's signatures can further subclassify breast cancer [16], leading to the identification of new molecular subtypes [17].

In this review, we will focus on novel prognostic and predictive markers of HER2-positive breast cancer subtype. HER2-positive breast cancer represents $15-20 \%$ of breast cancer cases $[18,19]$ and is defined by the overexpression of HER2 protein as characterized by immunohistochemistry (IHC) status or by florescence or chromogenic in situ hybridization (FISH/CISH) of HER2 gene copy number or a HER2/CEP17 ratio of 2 or greater [20]. This type of cancer is associated with poor prognosis, short survival, and high rates of recurrence [20].

\section{Human Epidermal Growth Factor Receptor (EGFR) Family}

EGFR are transmembrane receptors formed of three parts: An extracellular ligand binding site, a transmembrane part, and an intracellular tyrosine kinase domain that comprises of HER1, HER2, HER3, and HER4 [21]. The human epidermal growth factor receptor 2 (HER2) is a 1255 amino acid, $185 \mathrm{kD}$ localized on the long arm of chromosome 17q [22,23]. Activation of HER1, HER3, and HER4, occur through several ligands [24], including transforming growth factor alpha (TGF- $\alpha$ ), amphiregulin (for EGFR), EGF, and neuregulins (for HER3 and HER4) [25]. These signaling proteins control several cellular functions including cell proliferation, migration, differentiation, angiogenesis, and survival [26] via the downregulation of second messenger pathways as well as through cross talk with other membrane signaling pathways $[25,27,28]$.

HER2 receptor is highly expressed in human tissues including the cell membranes of epithelial cells in the gastrointestinal, respiratory, reproductive, and urinary tract as well as in the skin, breast, and placenta [29]. Amplification or overexpression of HER2 oncoprotein plays an important role in the pathogenesis of various solid tumors [30], including upper gastrointestinal tract (stomach and gastroesophageal junction adenocarcinoma) [31], ovarian cancer, colon, salivary gland [32], lung cancer, and breast cancer [33].

\section{HER2-Positive Breast Cancer}

Also known as HER2-enriched breast cancer, HER2-positive breast cancer represents $15-20 \%$ of all breast cancers $[18,19]$ and are dependent on the high expression of HER2 oncoprotein, and its intensive downstream signaling pathways [21].

The primary mechanism of HER2 activation in breast cancer is its gene amplification on the long arm of chromosome 17 (17q12-21-21.32) [34]; this consequently leads to the overexpression of HER2 protein (receptor) (Figure 1b) causing homo- or heterodimerization with other HER family members and resulting in auto- and transphosphorylation, which in turn activates several signaling pathways [19]. Among the most important pathways activated by HER2 overexpression is the phosphatidylinositol 3-kinase (PI3K), mammalian target of rapamycin (mTOR) axis, which are responsible for the regulation 
of important cellular functions including cellular metabolism, migration, as well as proliferation and angiogenesis [35-37]. Another important pathway activated by HER2 overexpression is the Ras/Raf/MEK/ERK pathway (also known as extracellular signal-regulated kinase/mitogen-activated protein kinase (ERK/MAPK) pathway) [19].
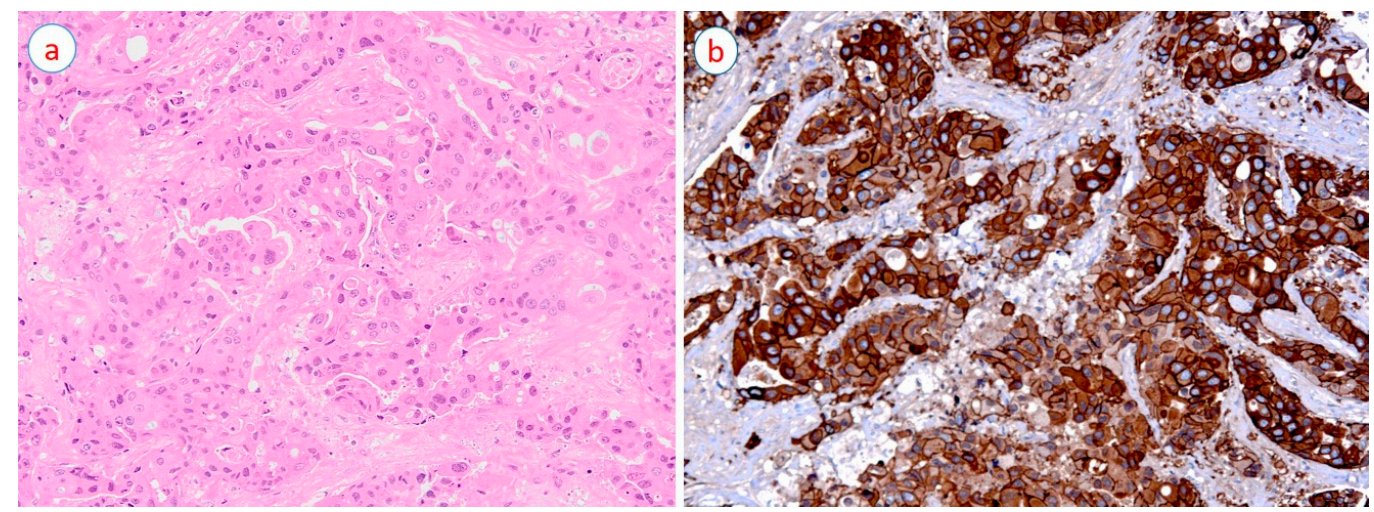

Figure 1. A case of high-grade invasive breast carcinoma (hematoxylin and eosin stain) (a) with diffuse (100\% of cancer cells) and strong (3+ intensity) human epidermal growth factor receptor 2 (HER2) expression $(10 \times)(\mathbf{b})$.

It is worth noting that HER2 status of breast cancer can change during the disease progression from negative to positive, one plausible reason being the oncogenic HER2 amplification during cancer progression [38-41].

Recent studies have also described HER2 mutations in a subset of breast cancers as well as other malignancies [42,43]. These mutations appear to be activating and driving breast carcinogenesis [44]. A systematic review of Petrelli et al. [42] revealed that the frequency of HER2 mutations in breast cancer is $\sim 3 \%$ with most of these affecting the intracellular (kinase) domain of HER2 receptor. Notably, HER2 mutations predominantly affect HER2-negative breast cancers (only 30\% are HER2 positive (amplified)) while $63 \%$ of breast cancers are ER+ [42]. HER2 mutations in breast cancer are also associated with poor outcomes [45].

HER2-positive breast cancers are morphologically poorly differentiated with a marked pleomorphism and a high proliferation rate (high grade cancers) (Figure 1a); they are prone to lymph node metastasis, tend to show a degree of resistance to certain chemotherapeutic agents [46], and have a higher rate of recurrence and distant metastasis, causing a high mortality rate [47].

Although approximately 50\% of all HER2-positive breast cancers express the steroid receptors estrogen (ER) or progesterone (PR) (luminal B breast cancers), they are usually resistant to endocrine treatment, particularly tamoxifen [48]. There is a growing clinical evidence that suggests the presence of a molecular crosstalk between ER and HER2 pathways [49,50], indicating ER+/HER2+ breast cancers as a distinct breast cancer subtype that may require a specific approach in treatment [51].

\section{Treatment of HER2-Positive Breast Cancer}

HER2-positive breast cancer is targeted by personalized therapy using monoclonal antibodies, such as trastuzumab (Herceptin), this treatment targets the HER2 receptor and blocks the related pathways inhibiting proliferation and survival as well as migration and cell invasion, leading to prolonged patient survival [52]. Moreover, other treatments such as lapatinib [53], pertuzumab as well as ado-trastuzumab emtansine (T-DM1) have also been approved for use in the treatment of HER2-positive breast cancer, particularly in metastatic setting [54]. Despite the availability of targeted therapy, almost $40 \%$ of patients with metastases develop primary resistance to trastuzumab and others, as approximately $60 \%$ of patients present with acquired resistance following one year of treatment [55].

Early diagnosis of breast cancer, as well as monitoring disease progression and its response to treatment, is critical in the management of this disease [56]. However, existing biomarkers and 
diagnostic tools, such as carcinoembryonic antigen (CEA) and carbohydrate antigens (CA), are of low sensitivity [57], therefore, clinicians cannot rely on these measures as screening tools. An ideal biomarker should be obtained noninvasively and be highly sensitive to detect the tumor as early as possible [58]. This new approach can have a major impact on the clinical management including breast cancer classification, prognosis, predicting therapy outcome, as well as follow-up after surgery and prediction of metastasis, and tumor recurrence.

\section{Gene Expression Profiling of HER2-Positive Breast Cancer}

Progress in microarray technology led to gene expression profiling of breast cancer with the aim of identifying patients that can benefit from adjuvant chemotherapy, and as a prognosis predictor in cancer patients $[59,60]$. HER2-positive breast cancers are a heterogeneous subgroup in which the resistance to treatment has been associated with specific gene expressions or gene mutations [61]. A recent study reported a genomic characterization of 64 HER2-positive breast cancer genomes. Based on genomic features including somatic mutations, copy-number changes, or structural variations, HER2-positive breast cancers are characterized into four subgroups (Groups A, B, C, and D). While subgroups A and B are ER+ and close to luminal B intrinsic subtype with low tumor protein p53 (TP53) values and amplification of cyclin D1 (CCND1) and ribosomal protein S6 Kinase B1 (RPS6KB1), groups $\mathrm{C}$ and D are ER- and close to the HER2-positive intrinsic subtype with high TP53 expression [61]. Moreover, a set of 20 key genes are classified according to their expression levels. Of these 20, 13 genes (Dickkopf-1 (DKK1), matrix metalloproteinase 15 (MMP15), baculoviral IAP repeat-containing 5 (BIRC5), CCND1, origin recognition complex subunit 6 homolog-like (ORC6L), MKi67, cyclin E1 (CCNE1), TP53, HER1/EGFR, ATPase H+ transporting V0 subunit a4 (ATP6V0A4), prolyl endopeptidase $(P R E P)$, reticulon 4 interacting protein 1 (RTN4IP1), kinesin-like protein (KIF18A)) are upregulated in HER2-positive breast cancer cells and correlated with poor survival rates because of their role in promoting proliferation, progression, lymph node, and metastasis (bone, lung, liver, and brain), and contributing to tumor aggressive behavior in colony growth. On the contrary, genes including phosphatidylinositol-4,5-bisphosphate 3-kinase catalytic subunit alpha (PIK3CA), phosphatase and tensin homolog (PTEN), inositol polyphosphate 4-phosphatase type II (INPP4B), phosphatidylinositol 3-kinase regulatory subunit (PIK3R1), TP63 are downregulated and resulted in poor prognosis and survival. In addition, several genes are studied as targets of recently developed drugs (Table 1). Overexpression of genes including post-GPI attachment to proteins 3 (PGAP3) [11] and growth factor receptor-bound protein 7 (GRB7) [11,14] are also associated with HER2 amplified breast cancers. While, 40-80\% HER2-positive breast cancer cases are known to harbor TP53 mutations [62,63].

Table 1. Gene expression profiling in HER2-positive breast cancer.

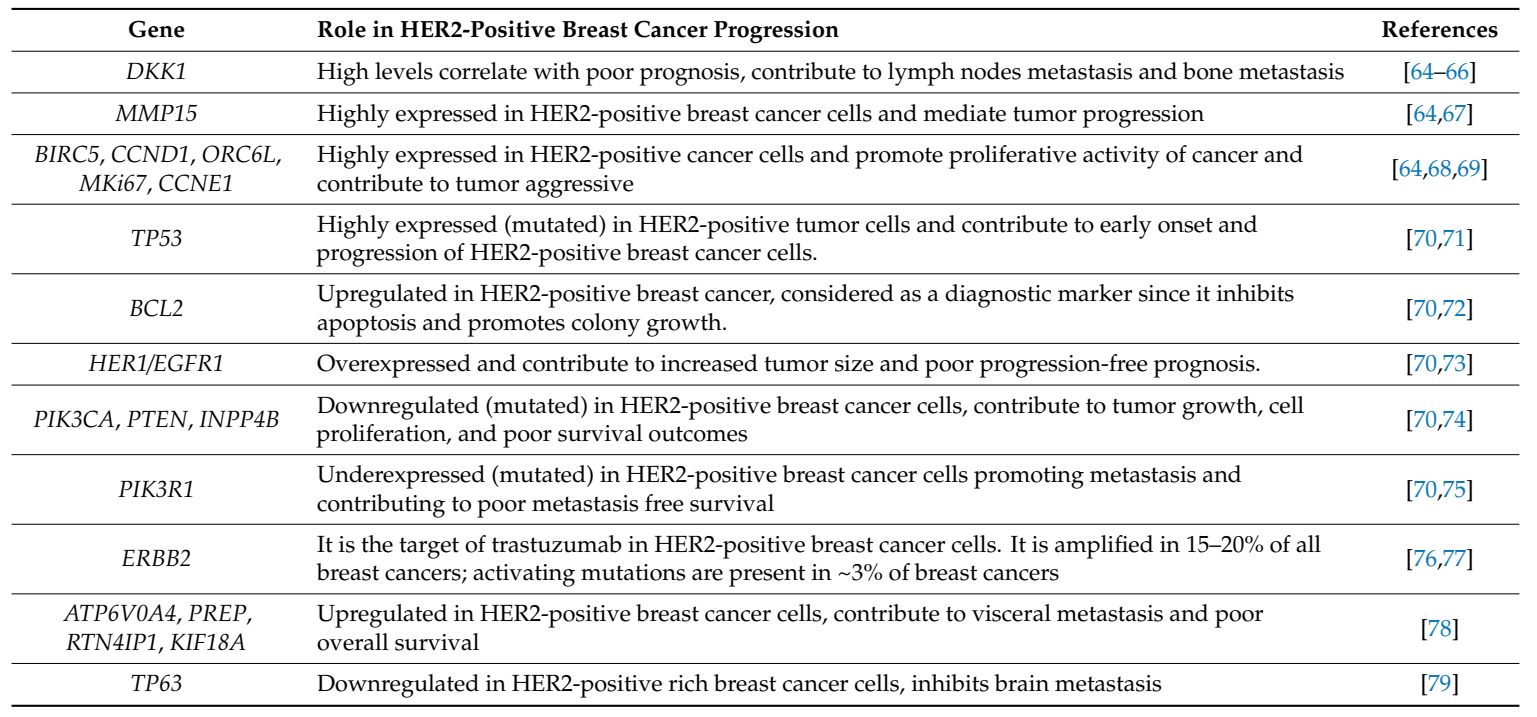


HER2-positive breast cancer patients generally benefit from neoadjuvant chemotherapy in the form of anthracyclines and taxanes with a higher complete pathological response in comparison with luminal and triple-negative subtypes [80]. Although molecular targeting agents such as trastuzumab are available, not all patients respond to it. The underlying mechanisms for resistance to trastuzumab still lies nascent, but few studies showed activation of the PI3K pathway [81] to be involved in drug resistance [82]. Activation of PI3K pathway through PIK3CA mutations, loss of PTEN [83] or C-X-C motif chemokine receptor type 4 (CXCR4) upregulation [80] can lead to cell growth through mTOR-mediated signaling [82]. Another study explored the genomic features of patients involved in a phase I/II study [84] using GeneChip microarray [82]. They found that mutations in B-Raf proto-oncogene, serine/threonine kinase (BRAF); EGFR1; PIK3CA; and proto-oncogene, receptor tyrosine kinase (KIT) are more frequent in trastuzumab-resistant HER2-positive metastatic breast cancer. These mutations may upregulate MAPK/ERK pathway and consequently induce resistance to trastuzumab. Furthermore, use of OncoScan ${ }^{\mathrm{tm}}$ detected mutations in five genes (catenin beta 1 (CTNNB1); HRas proto-oncogene, GTPase (HRAS); KRAS proto-oncogene, GTPase (KRAS); neurofibromin 2 (NF2); and SWI/SNF related, matrix associated, actin dependent regulator of chromatin, subfamily b, member 1 (SMARCB1) in HER2-positive breast cancer [82]. This study showed that trastuzumab-resistant ER+/HER2+ breast cancers carry genetic alterations that affect the DNA repair mechanism while trastuzumab-resistant ER-/HER2+ breast cancers carry mutations that activate mitotic signaling [82]. Another study analyzed hormone receptor (HR) status in HER2-positive breast cancer [85]. They used gene expression analysis to distinguish between HR-/HER2+ and HR+/HER2+. The authors found 127 differentially expressed genes [85]. The results of this investigation revealed that $83 \%$ of these genes are upregulated in HR-/HER2+ cohort of which 41 genes belong to the PI3K pathway, 26 genes are involved in transcriptional regulation and 22 genes are associated with MAPK pathway. This clearly indicates an active role of PI3K, and MAPK signaling pathways in HR-/HER2+ group [85].

\section{MicroRNA}

MicroRNAs (miRNAs) are a class of small regulatory, noncoding RNA molecules measuring approximately 18-25 nucleotides in length [86]. Since their initial discovery in Caenorhabditis elegans, they have been shown to play a major role in gene expression modulation and controlling major pathways [86].

miRNAs regulate the expression of $30-60 \%$ of human genes and are important modulators of cell proliferation, cell differentiation, cell development, cell-cycle progression, angiogenesis, epithelial-mesenchymal transition, stem cell renewal, apoptosis as well as cell migration, invasion, and metastasis [87]. Dysregulation in miRNA expression is associated with multiple human diseases such as cancer [88,89] and can act as promotor (oncomiR) or suppressors of tumorigenesis (antioncomiR) [90].

Recent studies showed that miRNAs can be detected not only in tissues but also in body fluids such as blood, serum, and urine, thus indicating miRNAs to be easily accessible without the need for invasive procedures [91]. Since miRNAs are highly stable, easily detectable in sera and can be measured easily by different techniques (deep sequencing, microarray as well as RT-qPCR) [87], they appear to be ideal biomarkers for diagnosis, follow-up, and prognosis prediction of cancer patients [92].

In the last decade, healthcare systems have greatly evolved, they have integrated point of care (POC) diagnostics as an integral part of their transformation [93]. POC allows the clinician to perform laboratory tests near the patient with quicker results, instead of conducting the tests in a routine laboratory set away from the patient, thus contributing to better patient care [94]. Since, the conventional assays (Northern blot, microarray assay, in situ hybridization, RT-qPCR, and next generation gene sequencing) are far from achieving the POC in breast cancer, development of miRNAs POC diagnostic tools and assays is a promising field of research in the upcoming decade as it can maximize diagnostic, prognostic, and predictive benefits for the patient [95-98]. New amplification and miRNAs detection assays are further being developed to fit criteria for POC diagnostics, the most promising ones being based on nanotechnology; however, they are yet to be integrated in clinical setting [93]. 
Numerous miRNAs have been reported to be dysregulated in human malignancies including lung, breast, ovarian, bladder, colon, and other types of carcinoma. Therefore, it is reasonable to assume that dysregulation in the miRNA machinery is a plausible reason for the onset and progression of human cancers [99]. Accumulating evidence indicates that miRNAs are dysregulated in all stages of breast cancer and thus can be used as diagnostic as well as prognostic and predictive biomarkers [100,101].

Previous studies reported that different breast cancer subtypes display various molecular miRNA signatures [16,100,102]. miRNAs have been dysregulated in breast cancer as shown by profiling breast tissues from healthy individuals and those from breast cancer patients [87]. Several miRNAs (miR-21, miR-10b, miR-155, and Let-7a) are found to be dysregulated in sera of breast cancer patients compared to healthy individuals [92,103-105]. Different miRNAs have been associated with specific breast cancer subtypes, specifically, Let-7f, Let-7c, and miR-10a are associated with luminal A, and miR155, miR-93, miR-18a, and miR-135b are associated with basal subtype [100]. On the other hand, miR-150 and miR-142-3p are associated with HER2-positive subtype [100], while miR-153, miR-10b, miR-26a, and miR146a, are shown to be potential biomarkers of triple negative subtype [106].

\section{MicroRNA and HER2-Positive Breast Cancer}

To date, only few studies have described the regulation of HER family receptors by miRNAs. Therefore, diagnostic and prognostic roles of miRNAs are still nascent and require further investigations [107].

A few studies have shown that miRNAs have a diagnostic role in HER2-positive breast cancer. miRNAs have been involved in the expression of 26 proteins within the EGFR1 signaling pathway. Among these, miR-147, miR-124, and miR-193-3p have been shown to act as tumor suppressors for the EGFR1 pathway, inhibiting the proliferation of HER2-positive breast cancers [108]. Another study identified 38 miRNAs inhibiting HER2 signaling and cell growth; the most vital miRNAs included miR-342-5p, miR-634, miR-491-5p, and miR-637 [109]. Furthermore, other miRNAs including miR-331-3p, miR-541, miR-134, miR-453, miR-193a-5p, miR-498, and miR-552 have also been identified as regulators of $3^{\prime} U T R$ of HER2 gene [109]. In comparison with HER2-negative breast cancers, the expression of two miRNAs (miR-342-5p and miR-744) was lost in HER2-positive breast cancer [109]. Another study identified downregulated expression of 43 miRNAs in HER2-positive breast cancer compared with HER2-negative breast cancer, indicating loss of miRNAs in HER2-positive breast cancers. This study further identified seven miRNAs specific to HER2-positive breast cancer. These include Let-7f, Let-7g, miR-107, miR-10b, miR-126, miR-154, and miR-195 [110]. A signature of 5 miRNAs (miR-520d, miR-181c, miR-302c, miR-376b, and miR-30e-3p) predicting HER2 status in patients with early breast cancer was also identified [111]. This study also revealed that miR-30b is differentially expressed between HER2-positive and HER2-negative breast cancers [111].

Furthermore, miRNAs also have a prognostic role in HER2-positive breast cancer. miRNA machinery elements, including Dicer, Drosha, DGCR8, Argonaut, and TRBP, and are reported to be involved in the progress of several cancer subtypes [99]. Thus, a study by Grelier et al. [112], suggested that DICER1 is significantly lower in the HER2-positive, luminal B, and basal-like subtypes and can be used as a predictive marker for metastases-free survival [16,112]. Another study conducted by Dedes et al. (2011) [113], reported the loss of DORSH to be associated with HER2 gene amplification and protein overexpression [113].

MicroRNA profiling has helped in enhancing breast cancer classification and in stratifying patients according to their response to therapy [114]. Du et al. [115] utilized miRNA microarrays and identified nine differentially expressed miRNAs between recurrent and nonrecurrent breast cancer patients. They developed a 2-miRNA (miR-4734 and miR-150-5p)-based prognostic signature that can be a reliable prognostic biomarker for patients with HER2-positive breast cancer [115]. This signature successfully classified patients into two groups based on the risk of tumor recurrence, independent of clinical characteristics, and predicted the five-year disease-free survival comparatively better than other clinicopathological factors, thus adding prognostic value to the TNM staging system [115]. 
While elevated miR-150 expression is associated with poorer clinical outcome in nonsmall-cell lung cancer [116] as well as triple negative breast cancer [117], miR-4734 has been recently identified in breast cancer by extensive next-generation sequencing analysis and encodes within the ERBB2/Her2 gene, which is upregulated in HER2-positive breast cancer patients [118].

Recent studies using relative real-time PCR analyzed differential expression of potential miRNAs to U6 RNA (noncoding small nuclear RNA which is conserved in all species [119]) in trastuzumab-resistant and trastuzumab-sensitive breast cancer cells [120]. The study showed that miR-23b-3p, miR-195-5p, miR-656-5p, and miR-340-5p are significantly dysregulated in trastuzumab-resistant cells and their potential targets are involved in drug resistance pathways (MAPK, PI3K-AKT, and FOXO). [120]. These miRNAs may be involved in the underlying mechanism for trastuzumab resistance, thus targeting these regulatory networks may help overcome trastuzumab resistance; however, further research is required to elucidate the clinical relevance of these observations [120].

One of the best characterized miRNAs in HER2-positive breast cancer is miR-21 [121]. It is located on chromosome 17-q 23.2 and may serve as a diagnostic biomarker for early breast cancer [122]. miR-21 is located on the intron of the protein coding gene TMEM49, however it was reported that miR-21 mostly has its own transcriptional system and is regulated independently [123]. The miR-21 promotor region contains several enhancer elements including sites that allow it to bind to activation protein 1 (AP-1), Nuclear factor-1 (NF1), SRF, TP53 and STAT3 (signal transducer and activator of transcription 3) [123]. Fujito et al. demonstrated, using the ChIP assays, that AP-1 stimulated the transcription of miR-21 initiating downregulation of NF1B1 expression. In addition, NF1B bound to the promotor region of miR-21 and negatively regulated it [123], implying that through this double-negative feedback loop miR-21 expression is sustained [124].

Previous studies have demonstrated that miR-21 acts as an oncogene by targeting tumor suppressor genes PDCD4 (programmed cell death 4), TPM-1 (tropomycin 1), and PTEN (phosphatase and tensin homolog) [125-127] (Figure 2). miR-21 is overexpressed in breast tumor tissues as well as in sera of patients when compared with controls [105]. In addition, PDCD4 expression is lost by the presence of miR-21 [128] in HER2-positive breast cancer cells [125]. PDCD4, a target of miR-21, is a regulator of AP1 and also induces the expression of cyclin dependent inhibitor (cdk) 21 [129].

miR-21 also enhances epithelial-mesenchymal transition, thus promoting progression of primary HER2-positive breast cancer [130]. Loss of PTEN stimulates IL-6, leading to upregulation of miR-21 thereby inducing EMT, which could be activated by PI3K and STAT3/NF-KB pathways [130] (Figure 2). Another study reported the role of TGF- $\beta$ in upregulating miR-21 expression in vascular smooth muscles (VSMCs), as well as in MDA-MB-468 breast cancer cells, through the SMAD signal pathway [131]. Another recent study conducted by Xiaomeng Dai et al. [132], demonstrated that upregulation of miR-21 in response to TGF- $\beta$, is associated with chemoresistance and cell invasion in vitro. In addition, inhibition of PTEN expression was found to be mediated by TGF- $\beta$ inducing increased expression of miR-21 in breast cancer cells; however, treatment of these cells with miR-21 inhibitor, restored PTEN expression [132]. miR-21 was also implicated in cell invasion and metastases in HER2-positive breast cancer. Overexpressed HER2 enhances the expression of miR-21, which could promote cell invasion of HER2-positive breast cancer through the stimulation of MAPK pathway [125].

miR-21 expression is enhanced via MAPK (ERK1/2) pathway upon activation of HER2/neu signaling in breast cancer cells [125]. A study conducted by Hatley et al., provided further evidence that miR-21 targeted the RAS pathway and activated the RAS/MEK/ERK pathway [133]. Therefore, miR-21 is considered a critical downstream player involved in HER2/neu-RAS-MEK-ERK signaling pathways that is majorly linked with the onset of various tumors including breast cancer [125]. Stimulation of ID-1 expression, enhanced by miR-21 upregulation, promote cell invasion as well as enhance oncogene signaling pathways associated with MEK-ERK pathway activation [134]. Moreover, since members of EGFR family, including HER1, HER2, HER3, or HER4, are known to stimulate the MEK-ERK pathway $[135,136]$, it can plausibly be involved in the enhanced expression of miR-21 in breast cancer cells. 


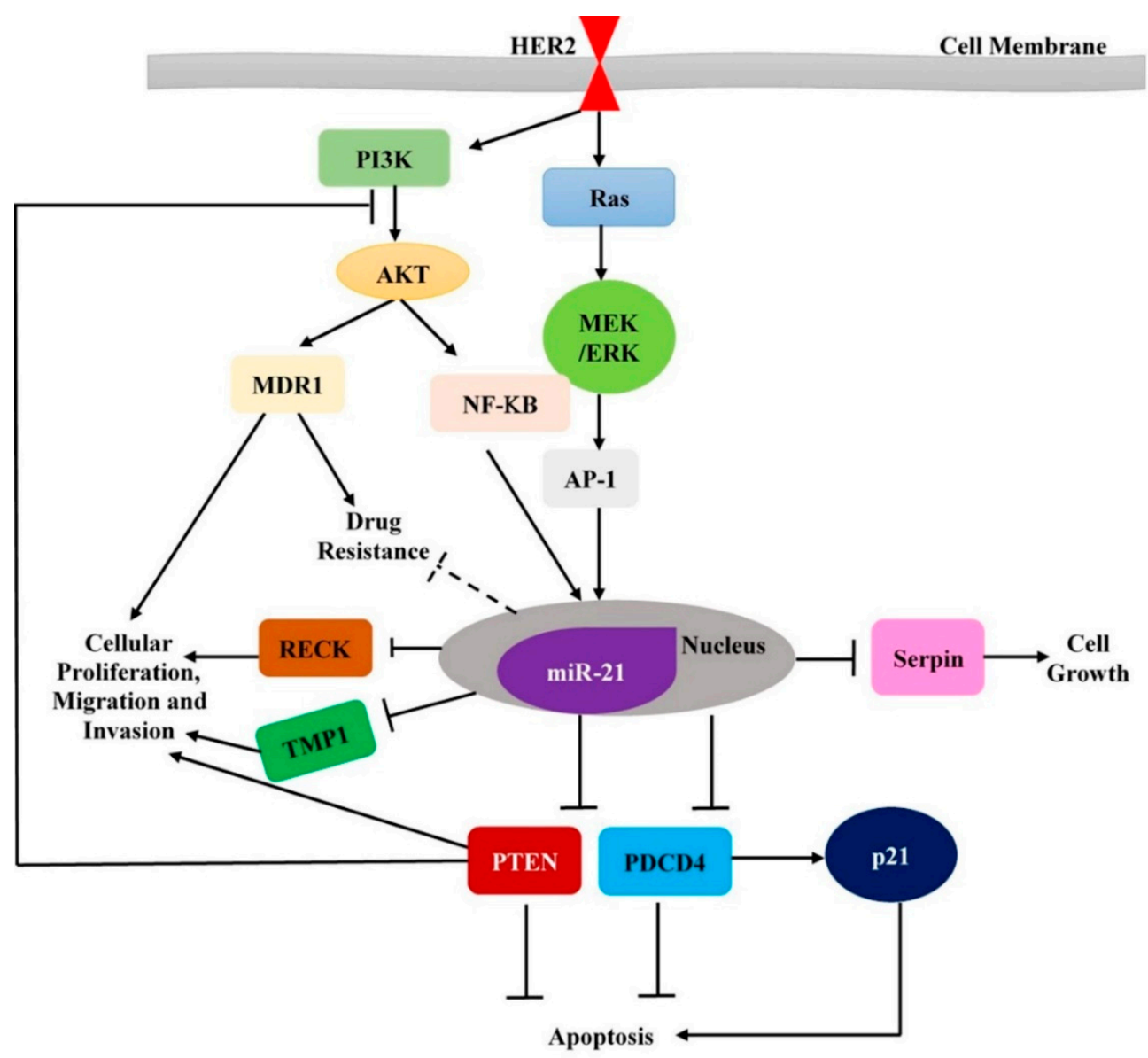

Figure 2. A schematic representation of the regulatory network displaying HER2-regulators-miRNAstargets (and crosstalk with canonical HER2 targets)-phenotypes.

MiR-21 was also found to significantly affect the response to neoadjuvant therapy in HER2-positive breast cancers [130]. DNA-damage due to chemotherapeutic drugs elevated miR-21 expression by stimulating NF- $\mathrm{KB}$, allowing breast cancer cells to escape DNA damage-induced apoptosis thus promoting their invasiveness [137]. This indicates overexpression of miR-21 can lead to resistance to trastuzumab-chemotherapy treatment in patients with HER2-positive breast cancer [130]. Another in vitro (SKBR3, BT474, and MDA-435) and in vivo (mammary fat pad of mice) study, showed that overexpression of miR-21 is correlated with poor response to trastuzumab in HER2-positive breast cancers [138]. In addition, it was shown that miR-21 is not associated with drug response in HER2-negative patients. Taken together, the body of evidence indicates the important role of miR-21 as a predictive biomarker for resistance to treatment (trastuzumab and cytotoxic drugs, such as cisplatin and paclitaxel) in HER2-positive patients [130].

Another important miRNA, miR-210, is located on chromosome 11p15.5 [139]. miR-210 levels are elevated in the plasma of HER2-positive breast cancer patients, and are associated with trastuzumab resistance as well as with tumor presence, lymph node metastases, and poor survival. It is also involved in tumor progression by targeting FBXO31 [140-142]. Therefore, it has been suggested that plasma levels of miR-210 can be useful in predicting and monitoring response to trastuzumab [143].

miR-489, located on chromosome 7q21.3 [144] has been described as one of the potential targets that downregulates HER2 signaling pathway, although the underlying mechanism remains nascent [109]. miR-489 expression is significantly decreased in HER2-positive breast cancers compared with luminal subtypes. Loss of miR-489 expression is observed in HER2-positive patients in comparison with normal breast tissues from the same patient [144]. Recent investigations indicated that elevated expression of miR-489 blocked cell growth, invasion and EMT by targeting Shp2 in hypopharyngeal carcinoma [145], 
SMAD3 in breast cancer [146], AKT3 in ovarian cancer [147], and Dek in ovarian cancer, as well as muscle stem cells $[147,148]$. Furthermore, Shp 2 was seen to enhance the RAS-MAPK pathway regulating breast cancer proliferation [144]. $\mathrm{miR}-489$ is a candidate miRNA that can be associated directly with the 3'-UTR of HER2 mRNA downregulating its expression [144]. miR-488 expression level is correlated with more aggressive tumor phenotype among HER2-positive breast cancers [144]. Furthermore, downregulated miR-489 enhances cancer cells resistance to chemotherapeutic drugs [149]; indicating that loss of miR-489 plays a role in tumor development and in anticancer drug sensitivity by regulating different target genes. Dysregulated expression of miR-489 enhances Smad3 expression activating EMT-like properties, thus conferring chemo-resistance [146]. Targeting miR489 as well as Smad3 [146] can be of substantial use in treatment of HER2-positive breast cancer [144]. Unregulated expression of miR-489 can aid to control aggressiveness of HER2-positive breast cancer.

Table 2 below summarizes key miRNAs with their expression levels and biological functions in HER2-positive breast cancer. Table 3 provides more details on the cellular position of miRNAs (intracellular or extracellular).

Table 2. A list of miRNAs and their roles in HER2-positive breast cancer.

\begin{tabular}{|c|c|c|c|}
\hline \multirow{2}{*}{$\begin{array}{l}\text { Biological } \\
\text { Functions }\end{array}$} & \multicolumn{2}{|c|}{ miRNAs } & \multirow{2}{*}{ References } \\
\hline & Stimulate & Inhibit & \\
\hline Cell proliferation & $\begin{array}{l}\text { miR-96, miR-96-5p, miR-10b, miR-143, } \\
\text { miR-127-3p, miR-19a, miR-222-3p }\end{array}$ & $\begin{array}{l}\text { miR-335-5p, miR-376a-3p, miR-452, } \\
\text { miR-182, miR-377-3p }\end{array}$ & {$[109,141,142,147,150-155]$} \\
\hline $\begin{array}{l}\text { Tumor metastases } \\
\text { and progression }\end{array}$ & $\begin{array}{c}\text { miR-96, miR-96-5pm miR-10b, miR-127-3p, } \\
\text { miR-320, miR-19a, miR-221, miR-221-3p, } \\
\text { miR-17, miR-222-3p, miR-9-5p }\end{array}$ & $\begin{array}{l}\text { miR-148a, miR-148a-3p, miR-148b-3p, } \\
\text { miR-335-5p, miR-376a-3p, miR-452, } \\
\text { miR-182, miR-377-3p }\end{array}$ & {$[109,141,142,147,150,151,153-159]$} \\
\hline Cell Apoptosis & $\begin{array}{l}\text { miR-148a, miR-148a-3p, miR-148b-3p, } \\
\text { miR-376a-3p, miR-452, miR-468 }\end{array}$ & miR-221, miR-221-3p & {$[109,141,142,153,156,157]$} \\
\hline $\begin{array}{l}\text { Resistance to } \\
\text { therapy }\end{array}$ & $\begin{array}{l}\text { miR-200, miR-200c, miR-221, miR-100, } \\
\text { miR-222-3p, miR-9-5p }\end{array}$ & & {$[142,156,159,160]$} \\
\hline
\end{tabular}

Table 3. Localization of miRNAs.

\begin{tabular}{ccc}
\hline miRNAs & Intracellular/Extracellular & References \\
\hline miR-96 & Extracellular & {$[161,162]$} \\
miR-96-5p & Extracellular and Intracellular & {$[87,163]$} \\
miR10-b & Extracellular and Intracellular & {$[164]$} \\
miR-143 & Extracellular and Intracellular & {$[164]$} \\
miR-127-3p & Extracellular & {$[87,165]$} \\
miR-19-a & Extracellular and Intracellular & {$[164]$} \\
miR-7 & Extracellular & {$[161,165]$} \\
miR-148-a & Extracellular & {$[164]$} \\
miR-200c & Intracellular & {$[166]$} \\
miR-100 & Intracellular & {$[164]$} \\
miR-452 & Extracellular and Intracellular & {$[164]$} \\
miR-182 & Extracellular and Intracellular & {$[87,167]$} \\
miR-148a & Extracellular & {$[164]$} \\
miR-148b-3p & Extracellular & {$[87,168]$} \\
miR-221 & Intracellular & {$[110,161]$} \\
\hline
\end{tabular}

\section{Clinical Relevance of miRNAs in HER2-Positive Breast Cancer}

As mentioned above, miRNAs have been involved in the onset and progression of breast cancer and have the ability to reverse resistance to drugs like tamoxifen; as studies have shown that re-expression of miR-375 [169], miR-342 [170], and miR-449a [171] suppressed tamoxifen resistance; indicating them to be potential biomarkers for therapeutic strategies. miR-210 levels in plasma are linked with trastuzumab resistance in HER2-positive breast cancer patients [172]. A recent study showed that enhanced levels of miR-770-5p interfere with trastuzumab effectiveness; increased miR-770-5p levels downregulated the total or phosphorylated levels of AKT and ERK, that are the two main regulator 
proteins of PI3K and MAPK signaling pathways [173]. The study further indicated a synergistic role of miR-770-5p with tyrosine kinase inhibitors as an effective therapeutic strategy for breast cancer; however, further research is needed to confirm the efficacy of the combination in vivo [173]. Another study identified a tumor suppressive role of miR-1296-5p in HER2-positive breast cancer cells; increased miR-1296-5p levels reduced its target protein level and mTORC1/S6 activation; thus, miR-1296-5p is able to block cellular proliferation of HER2-positive breast cancer cells and increase their sensitivity to cisplatin and 5-fluorouracil-induced apoptosis [174]. A very recent study by Yang et al., [175] identified three upregulated miRNAs (miR-200b, miR-135b, and miR-29a) and one downregulated miRNA (miR-224) in trastuzumab-resistant breast cancer samples in comparison to trastuzumab-sensitive breast cancers. The study provided further evidence that miRNAs may be reliable biomarkers of the response to anti-HER2 drugs [175]. Another study identified two downregulated miRNAs (miR-141 and miR-375) in trastuzumab-resistant breast cancer cells [176]. Furthermore, silencing of miR-141 enhanced ERBB4 expression, which plays a critical role in trastuzumab resistance in breast cancer cells; taken together, these results indicate that both miR-141 as well as its target, ERBB4, may be potential tools for the efficient treatment of trastuzumab-resistant breast cancers [176].

On the other hand, amplification in the 17q23 region (amplicon) leads to dysregulated expression of oncogene WIP1 and oncomiR, miR-21; both of which have been involved in promoting breast tumorigenesis as well as resistance to anti-HER2 therapies [177]. Research by Lui et al., (2018) [177] showed that knockdown of both WIP1 and miR-21, reduced proliferation, survival, and tumorigenic potential of HER2-positive breast cancer cells harboring 17q23 amplification, thus, providing an effective therapeutic strategy for HER2-positive breast cancers [177]. Development of $\mathrm{pH}$-sensitive nanoparticles that are capable of capturing WIP1 and miR-21 inhibitors will aid in paving the way for effective future therapeutic approaches against trastuzumab-resistant breast cancers [177].

miRNAs are usually present in microvesicles or bound to lipoproteins in the blood [178]; while several miRNAs in body fluids are concentrated in exosomes [179]. Recently, exosomal miRNAs in body fluids have been shown to play a diagnostic role in several cancers including breast [180-182]. Cancer patients frequently display increased levels of tumor-derived exosomes in plasma or serum compared with those in healthy donors [183]. A recent study identified 11 exosomal miRNAs (miR-338-3p, miR-340-5p and miR-124-3p, miR-29b-3p, miR-20b-5p, miR-17-5p, miR-130a-3p, miR-18a-5p, miR-195-5p, miR-486-5p, and miR-93-5p) in serum of patients associated with breast cancer recurrence [183]. Another study revealed differential expression of exosomal miR-101 and miR-373 between patients with breast cancer and benign breast tumors; exosomal miR-101 serum levels were dysregulated in HER2-positive breast cancer compared with their levels in healthy women [184]. Studies have also shown that lack of estrogen stimulation may significantly increase miR-101-mediated activation of the Akt signaling pathway [185], thus promoting increased cell survival and malignant progression of breast cancer [186]. Research focusing on the underlying mechanism of secretion of miRNAs into exosomes or the retention of miRNAs inside cancer cells is still poorly understood. Further clinical and functional validation studies are essential for future application of these miRNAs.

\section{Conclusions}

HER2-positive breast cancer is an aggressive subtype of breast cancer with a poor outcome despite available targeted treatment modalities. There is an increasing body of evidence that various gene and miRNA signatures are specific for HER2-positive breast cancer. None of these has become fully clinically applicable and therefore, further studies are necessary for their validation. More specifically, there is a huge gap regarding the miRNA profile of HER2-positive breast cancer, therefore, it is necessary to conduct more in-depth studies, which may lead to specific miRNA markers or targets for HER2-positive breast cancers.

On the other hand, it is important to develop an animal model for HER2-positive breast cancer, which can be used to study the miRNA and gene profile of the main metastatic sites of HER2-positive 
breast cancer metastasis, more specifically, brain and lung. Such a study may allow to develop specific markers for metastatic HER2-positive breast cancers.

Author Contributions: R.M.S.; writing-original draft preparation, I.G., I.A.-H., H.A.A.-T., H.F.A.F., and S.V.; writing-review and editing; A.-E.A.M.; original concept, writing—-review and editing.

Funding: Research of Al Moustafa's and Vranic's labs have been supported by grants from Qatar University: QUCG-CMED-2018\2019-3, QUCP-CMED-2019-1 and QUST-1-CMED-2019-18.

Acknowledgments: We are thankful to Amal Kassab for her critical reading of the manuscript. The publication of this article was funded by the Qatar National Library.

Conflicts of Interest: The authors declare no conflict of interest.

\section{References}

1. Bray, F.; Ferlay, J.; Soerjomataram, I.; Siegel, R.L.; Torre, L.A.; Jemal, A. Global cancer statistics 2018: Globocan estimates of incidence and mortality worldwide for 36 cancers in 185 countries. CA Cancer J. Clin. 2018, 68, 394-424. [CrossRef] [PubMed]

2. Redig, A.J.; McAllister, S.S. Breast cancer as a systemic disease: A view of metastasis. J. Int. Med. 2013, 274, 113-126. [CrossRef]

3. Eroles, P.; Bosch, A.; Pérez-fidalgo, J.A.; Lluch, A. Molecular biology in breast cancer: Intrinsic subtypes and signaling pathways. Cancer Treat. Rev. 2012, 38, 698-707. [CrossRef] [PubMed]

4. Kelsey, J.L.; Gammon, M.D.; John, E.M. Reproductive factors and breast cancer. Epidemiol. Rev. 1993, 15, 36-47. [CrossRef]

5. Beral, V.; Reeves, G. Childbearing, oral contraceptive use, and breast cancer. Lancet 1993, 341, 1102. [CrossRef]

6. Engin, A. Obesity-associated breast cancer: Analysis of risk factors. In Obesity and lipotoxicity; Engin, A.B., Engin, A., Eds.; Springer International Publishing: Cham, Switzerland, 2017; pp. 571-606.

7. Key, T.J.; Verkasalo, P.K. Endogenous hormones and the aetiology of breast cancer. Breast Cancer Res. 1999, 1, 18-21. [CrossRef]

8. Key, T.J.; Verkasalo, P.K.; Banks, E. Epidemiology of breast cancer. Lancet Oncol. 2001, 2, 133-140. [CrossRef]

9. Schnitt, S.J. Classification and prognosis of invasive breast cancer: From morphology to molecular taxonomy. Mod. Pathol. 2010, 23, 60-64. [CrossRef]

10. Reis-Filho, J.S.; Pusztai, L. Gene expression profiling in breast cancer: Classification, prognostication, and prediction. Lancet 2011, 378, 1812-1823. [CrossRef]

11. Dai, X.; Chen, A.; Bai, Z. Integrative investigation on breast cancer in ER, PR and HER2-defined subgroups using mRNA and miRNA expression profiling. Sci. Rep. 2014, 4, 6566. [CrossRef]

12. Iwamoto, T.; Pusztai, L. Predicting prognosis of breast cancer with gene signatures: Are we lost in a sea of data? Genome Med. 2010, 2, 2-5. [CrossRef]

13. Prat, A.; Parker, J.S.; Karginova, O.; Fan, C.; Livasy, C.; Herschkowitz, J.I.; He, X.; Perou, C.M. Phenotypic and molecular characterization of the claudin-low intrinsic subtype of breast cancer. Cancer Res. 2010, 12, R68. [CrossRef]

14. Perou, C.M.; Sørlie, T.; Eisen, M.B.; van de Rijn, M.; Jeffrey, S.S.; Rees, C.A.; Pollack, J.R.; Ross, D.T.; Johnsen, H.; Akslen, L.A.; et al. Molecular portraits of human breast tumours. Nature 2000, 406, 747-752. [CrossRef] [PubMed]

15. Sørlie, T.; Perou, C.M.; Tibshirani, R.; Aas, T.; Geisler, S.; Johnsen, H.; Hastie, T.; Eisen, M.B.; van de Rijn, M.; Jeffrey, S.S.; et al. Gene expression patterns of breast carcinomas distinguish tumor subclasses with clinical implications. Proc. Natl. Acad. Sci. USA 2001, 98, 10869-10874. [CrossRef] [PubMed]

16. Blenkiron, C.; Goldstein, L.D.; Thorne, N.P.; Spiteri, I.; Chin, S.-F.; Dunning, M.J.; Miska, E.A. MicroRNA expression profiling of human breast cancer identifies new markers of tumor subtype. Genome Biol. 2007, 8, R214. [CrossRef] [PubMed]

17. Bhattacharyya, M.; Nath, J.; Bandyopadhyay, S. MicroRNA signatures highlight new breast cancer subtypes. Gene 2015, 556, 192-198. [CrossRef]

18. Loibl, S.; Gianni, L. HER2-positive breast cancer. Lancet 2017, 389, 2415-2429. [CrossRef]

19. Asif, H.; Sultana, S.; Ahmed, S.; Akhtar, N.; Tariq, M. HER-2 positive breast cancer-A mini-review. Asian Pac. J. Cancer Prev. 2016, 17, 1609-1615. [CrossRef] 
20. Wolff, A.C.; Hammond, M.E.H.; Allison, K.H.; Harvey, B.E.; Mangu, P.B.; Bartlett, J.M.S.; Bilous, M.; Ellis, I.O.; Fitzgibbons, P.; Hanna, W.; et al. Human epidermal growth factor receptor 2 testing in breast cancer: American society of clinical oncology/college of american pathologists clinical practice guideline focused update. Arch. Pathol. Lab. Med. 2018, 142, 1364-1382. [CrossRef]

21. Chien, A.J.; Rugo, H.S. Tyrosine kinase inhibitors for human epidermal growth factor receptor 2-positive metastatic breast cancer: Is personalizing therapy within reach? J. Clin. Oncol. 2017, 35, 3089-3091. [CrossRef]

22. Brandt-Rauf, P.W.; Pincus, M.R.; Carney, W.P. The c-ERBB-2 protein in oncogenesis: Molecular structure to molecular epidemiology. Crit. Rev. Oncog. 1994, 5, 313-329. [CrossRef]

23. Zhongren, Z.; Hick, D.G. HER2 amplification or overexpression in upper gi tract and breast cancer with clinical diagnosis and treatment. In Oncogene and Cancer-From Bench to Clinic; Yahwardiah, S., Ed.; IntechOpen: London, UK, 2013; pp. 68-90. ISBN 978-953-51-0858-0.

24. Bertelsen, V.; Stang, E. The mysterious ways of ERBB2/HER2 trafficking. Membranes 2014, 4, 424-446. [CrossRef] [PubMed]

25. Larionov, A.A. Current therapies for human epidermal growth factor receptor 2-positive metastatic breast cancer patients. Front. Oncol. 2018, 8, 89. [CrossRef]

26. Connell, C.M.; Doherty, G.J. Activating HER2 mutations as emerging targets in multiple solid cancers. ESMO Open 2017, 2, e000279. [CrossRef] [PubMed]

27. Citri, A.; Yarden, Y. EGF-ERBB signalling: Towards the systems level. Nat. Rev. Mol. Cell Biol. 2006, 7, 505-516. [CrossRef] [PubMed]

28. Moasser, M.M. The oncogene HER2: Its signaling and transforming functions and its role in human cancer pathogenesis. Oncogene 2007, 26, 6469-6487. [CrossRef] [PubMed]

29. Press, M.; Cordon-Cardo, C.; Slamon, D.J. Expression of the HER-2/NEU proto-oncogene in normal human adult and fetal tissues. Oncogene 1990, 5, 953-962. [PubMed]

30. Iqbal, N.; Iqbal, N. Human epidermal growth factor receptor 2 (HER2) in cancers: Overexpression and therapeutic implications. Mol. Biol. Int. 2014, 2014, 852748. [CrossRef]

31. Jørgensen, J.T.; Nielsen, K.B.; Kjærsgaard, G.; Jepsen, A.; Mollerup, J. Gene signal distribution and HER2 amplification in gastroesophageal cancer. J. Cancer 2017, 8, 1517-1524. [CrossRef]

32. Honarvar, H.; Calce, E.; Doti, N.; Langella, E.; Orlova, A.; Buijs, J.; D’Amato, V.; Bianco, R.; Saviano, M.; Tolmachev, V.; et al. Evaluation of HER2-specific peptide ligand for its employment as radiolabeled imaging probe. Sci. Rep. 2018, 8, 2998. [CrossRef]

33. Langdon, S. Targeting HER2-driven cancers in non-breast cancer malignancies. J. Mol. Biomark. Diagn 2012, 3, e105. [CrossRef]

34. Nassar, A.; Khoor, A.; Radhakrishnan, R.; Radhakrishnan, A.; Cohen, C. Correlation of HER2 overexpression with gene amplification and its relation to chromosome 17 aneuploidy: A 5-year experience with invasive ductal and lobular carcinomas. Int. J. Clin. Exp. Pathol. 2014, 7, 6254-6261.

35. Guertin, D.A.; Sabatini, D.M. Defining the role of mtor in cancer. Cancer Cell 2007, 12, 9-22. [CrossRef]

36. Serra, V.; Scaltriti, M.; Prudkin, L.; Eichhorn, P.J.A.; Ibrahim, Y.H.; Chandarlapaty, S.; Markman, B.; Rodriguez, O.; Guzman, M.; Rodriguez, S.; et al. Pi3k inhibition results in enhanced her signaling and acquired erk dependency in HER2-overexpressing breast cancer. Oncogene 2011, 30, 2547-2557. [CrossRef]

37. Yarden, Y.; Shilo, B.-Z. Snapshot: EGFR signaling pathway. Cell 2007, 131, 1018. [CrossRef]

38. Wülfing, P.; Borchard, J.; Buerger, H.; Heidl, S.; Zänker, K.S.; Kiesel, L.; Brandt, B. HER2-positive circulating tumor cells indicate poor clinical outcome in stage i to iii breast cancer patients. Clin. Cancer Res. 2006, 12, 1715-1720. [CrossRef]

39. Hayes, D.F.; Walker, T.M.; Singh, B.; Vitetta, E.S.; Uhr, J.W.; Gross, S.; Rao, C.; Doyle, G.V.; Terstappen, L.W. Monitoring expression of her-2 on circulating epithelial cells in patients with advanced breast cancer. Int. J. Oncol. 2002, 21, 1111-1117. [CrossRef]

40. Meng, S.; Tripathy, D.; Shete, S.; Ashfaq, R.; Haley, B.; Perkins, S.; Beitsch, P.; Khan, A.; Euhus, D.; Osborne, C.; et al. Her-2 gene amplification can be acquired as breast cancer progresses. Proc. Natl. Acad. Sci. USA 2004, 101, 9393-9398. [CrossRef]

41. Wang, C.-H.; Chang, C.-J.; Yeh, K.-Y.; Chang, P.-H.; Huang, J.-S. The prognostic value of HER2-positive circulating tumor cells in breast cancer patients: A systematic review and meta-analysis. Clin. Breast Cancer 2017, 17, 341-349. [CrossRef] 
42. Petrelli, F.; Tomasello, G.; Barni, S.; Lonati, V.; Passalacqua, R.; Ghidini, M. Clinical and pathological characterization of HER2 mutations in human breast cancer: A systematic review of the literature. Breast Cancer Res. Treat. 2017, 166, 339-349. [CrossRef] [PubMed]

43. Wen, W.; Chen, W.S.; Xiao, N.; Bender, R.; Ghazalpour, A.; Tan, Z.; Swensen, J.; Millis, S.Z.; Basu, G.; Gatalica, Z.; et al. Mutations in the kinase domain of the HER2/ERBB2 gene identified in a wide variety of human cancers. JMD 2015, 17, 487-495. [CrossRef] [PubMed]

44. Bose, R.; Kavuri, S.M.; Searleman, A.C.; Shen, W.; Shen, D.; Koboldt, D.C.; Monsey, J.; Goel, N.; Aronson, A.B.; $\mathrm{Li}$, S.; et al. Activating HER2 mutations in HER2 gene amplification negative breast cancer. Cancer Discovery 2013, 3, 224-237. [CrossRef] [PubMed]

45. Wang, T.; Xu, Y.; Sheng, S.; Yuan, H.; Ouyang, T.; Li, J.; Wang, T.; Fan, Z.; Fan, T.; Lin, B.; et al. HER2 somatic mutations are associated with poor survival in HER2-negative breast cancers. Cancer Sci. 2017, 108, 671-677. [CrossRef]

46. Burstein, H.J. The distinctive nature of HER2-positive breast cancers. N. Engl. J. Med. 2005, 353, 1652-1654. [CrossRef] [PubMed]

47. Mitri, Z.; Constantine, T.; O'Regan, R. The HER2 receptor in breast cancer: Pathophysiology, clinical use, and new advances in therapy. Chemother. Res. and Pract. 2012, 2012, 743193. [CrossRef]

48. Azim, H.; Piccart, M. Simultaneous targeting of estrogen receptor and HER2 in breast cancer. Expert Rev. Anticancer Ther. 2010, 10, 1255-1263. [CrossRef]

49. Massarweh, S.; Schiff, R. Unraveling the mechanisms of endocrine resistance in breast cancer: New therapeutic opportunities. Clin. Cancer Res. 2007, 13, 1950-1954. [CrossRef]

50. Arpino, G.; Wiechmann, L.; Osborne, C.K.; Schiff, R. Crosstalk between the estrogen receptor and the HER tyrosine kinase receptor family: Molecular mechanism and clinical implications for endocrine therapy resistance. Endocr. Rev. 2008, 29, 217-233. [CrossRef]

51. Lousberg, L.; Collignon, J.; Jerusalem, G. Resistance to therapy in estrogen receptor positive and human epidermal growth factor 2 positive breast cancers: Progress with latest therapeutic strategies. Ther. Adv. Med. Oncol. 2016, 8, 429-449. [CrossRef]

52. Marty, M.; Cognetti, F.; Maraninchi, D.; Snyder, R.; Mauriac, L.; Tubiana-Hulin, M.; Chan, S.; Grimes, D.; Antón, A.; Lluch, A.; et al. Randomized phase ii trial of the efficacy and safety of trastuzumab combined with docetaxel in patients with human epidermal growth factor receptor 2-positive metastatic breast cancer administered as first-line treatment: The m77001 study group. J. Clin. Oncol. 2005, 23, 4265-4274. [CrossRef]

53. Geyer, C.E.; Forster, J.; Lindquist, D.; Chan, S.; Romieu, C.G.; Pienkowski, T.; Jagiello-Gruszfeld, A.; Crown, J.; Chan, A.; Kaufman, B.; et al. Lapatinib plus capecitabine for HER2-positive advanced breast cancer. N. Engl. J. Med. 2006, 355, 2733-2743. [CrossRef]

54. Peddi, P.F.; Hurvitz, S.A. Ado-trastuzumab emtansine (t-DM1) in human epidermal growth factor receptor 2 (HER2)-positive metastatic breast cancer: Latest evidence and clinical potential. Ther. Adv. Med. Oncol. 2014, 6, 202-209. [CrossRef] [PubMed]

55. Brufsky, A. Trastuzumab-based therapy for patients with HER2-positive breast cancer: From early scientific development to foundation of care. Am. J. Clin. Oncol. 2010, 33, 186-195. [CrossRef]

56. Cappelletti, V.; Appierto, V.; Tiberio, P.; Fina, E.; Callari, M.; Daidone, M.G. Circulating biomarkers for prediction of treatment response. JNCI Monogr. 2015, 2015, 60-63. [CrossRef]

57. Heneghan, H.M.; Miller, N.; Lowery, A.J.; Sweeney, K.J.; Kerin, M.J. MicroRNAs as novel biomarkers for breast cancer. J. Oncol. 2010, 2009, 950201. [CrossRef]

58. Chen, X.; Ba, Y.; Ma, L.; Cai, X.; Yin, Y.; Wang, K.; Guo, J.; Zhang, Y.; Chen, J.; Guo, X.; et al. Characterization of microRNAs in serum: A novel class of biomarkers for diagnosis of cancer and other diseases. Cell Res. 2008, 18, 997-1006. [CrossRef]

59. Sotiriou, C.; Pusztai, L. Gene-expression signatures in breast cancer. N. Engl. J. Med. 2009, 360, 790-800. [CrossRef]

60. Weigelt, B.; Baehner, F.L.; Reis-Filho, J.S. The contribution of gene expression profiling to breast cancer classification, prognostication and prediction: A retrospective of the last decade. J. Pathol. 2010, 220, 263-280. [CrossRef] [PubMed]

61. Ferrari, A.; Vincent-Salomon, A.; Pivot, X.; Sertier, A.-S.; Thomas, E.; Tonon, L.; Boyault, S.; Mulugeta, E.; Treilleux, I.; MacGrogan, G.; et al. A whole-genome sequence and transcriptome perspective on HER2-positive breast cancers. Nat. Commun. 2016, 7, 12222. [CrossRef] 
62. Dai, X.; Li, T.; Bai, Z.; Yang, Y.; Liu, X.; Zhan, J.; Shi, B. Breast cancer intrinsic subtype classification, clinical use and future trends. Am. J. Cancer Res. 2015, 5, 2929-2943.

63. Darb-Esfahani, S.; Denkert, C.; Stenzinger, A.; Salat, C.; Sinn, B.; Schem, C.; Endris, V.; Klare, P.; Schmitt, W.; Blohmer, J.-U.; et al. Role of tp53 mutations in triple negative and HER2-positive breast cancer treated with neoadjuvant anthracycline/taxane-based chemotherapy. Oncotarget 2016, 7, 67686-67698. [CrossRef]

64. Rahmatpanah, F.B.; Jia, Z.; Chen, X.; Char, J.E.; Men, B.; Franke, A.-C.; Jones, F.E.; McClelland, M.; Mercola, D. A class of genes in the HER2 regulon that is poised for transcription in breast cancer cell lines and expressed in human breast tumors. Oncotarget 2014, 6, 1286-1301. [CrossRef] [PubMed]

65. Xu, W.-H.; Liu, Z.-B.; Yang, C.; Qin, W.; Shao, Z.-M. Expression of dickkopf-1 and beta-catenin related to the prognosis of breast cancer patients with triple negative phenotype. PLoS ONE 2012, 7, e37624. [CrossRef] [PubMed]

66. Kasoha, M.; Bohle, R.M.; Seibold, A.; Gerlinger, C.; Juhasz-Böss, I.; Solomayer, E.-F. Dickkopf-1 (dkk1) protein expression in breast cancer with special reference to bone metastases. Clin. Exp. Metastasis 2018, 35, 763-775. [CrossRef]

67. McGowan, P.M.; Duffy, M.J. Matrix metalloproteinase expression and outcome in patients with breast cancer: Analysis of a published database. Ann. Oncol. 2008, 19, 1566-1572. [CrossRef] [PubMed]

68. Bernhardt, S.M.; Dasari, P.; Walsh, D.; Townsend, A.R.; Price, T.J.; Ingman, W.V. Hormonal modulation of breast cancer gene expression: Implications for intrinsic subtyping in premenopausal women. Front. Oncol. 2016, 6, 241. [CrossRef] [PubMed]

69. Mohammadizadeh, F.; Hani, M.; Ranaee, M.; Bagheri, M. Role of cyclin d1 in breast carcinoma. J. Res. Med. Sci. 2013, 18, 1021-1025.

70. Cancer Genome Atlas, N. Comprehensive molecular portraits of human breast tumours. Nature 2012, 490, 61-70.

71. Melhem-Bertrandt, A.; Bojadzieva, J.; Ready, K.J.; Obeid, E.; Liu, D.D.; Gutierrez-Barrera, A.M.; Litton, J.K.; Olopade, O.I.; Hortobagyi, G.N.; Strong, L.C.; et al. Early onset HER2-positive breast cancer is associated with germline tp53 mutations. Cancer 2012, 118, 908-913. [CrossRef] [PubMed]

72. Eom, Y.H.; Kim, H.S.; Lee, A.; Song, B.J.; Chae, B.J. BCL2 as a subtype-specific prognostic marker for breast cancer. J. Breast Cancer 2016, 19, 252-260. [CrossRef]

73. Hsu, J.L.; Hung, M.-C. The role of HER2, egfr, and other receptor tyrosine kinases in breast cancer. Cancer Metastasis Rev. 2016, 35, 575-588. [CrossRef]

74. Stern, H.M.; Gardner, H.; Burzykowski, T.; Elatre, W.; O’Brien, C.; Lackner, M.R.; Pestano, G.A.; Santiago, A.; Villalobos, I.; Eiermann, W.; et al. Pten loss is associated with worse outcome in HER2-amplified breast cancer patients but is not associated with trastuzumab resistance. Clin. Cancer Res. 2015, 21, 2065-2074. [CrossRef]

75. Cizkova, M.; Vacher, S.; Meseure, D.; Trassard, M.; Susini, A.; Mlcuchova, D.; Callens, C.; Rouleau, E.; Spyratos, F.; Lidereau, R.; et al. Pik3r1 underexpression is an independent prognostic marker in breast cancer. BMC Cancer 2013, 13, 545. [CrossRef] [PubMed]

76. Rangel, N.; Villegas, V.E.; Rondón-Lagos, M. Profiling of gene expression regulated by $17 \beta$-estradiol and tamoxifen in estrogen receptor-positive and estrogen receptor-negative human breast cancer cell lines. Breast Cancer 2017, 9, 537-550.

77. Wirapati, P.; Sotiriou, C.; Kunkel, S.; Farmer, P.; Pradervand, S.; Haibe-Kains, B.; Desmedt, C.; Ignatiadis, M.; Sengstag, T.; Schütz, F.; et al. Meta-analysis of gene expression profiles in breast cancer: Toward a unified understanding of breast cancer subtyping and prognosis signatures. Breast Cancer Res. 2008, 10, R65. [CrossRef]

78. Savci-Heijink, C.D.; Halfwerk, H.; Koster, J.; Horlings, H.M.; van de Vijver, M.J. A specific gene expression signature for visceral organ metastasis in breast cancer. BMC Cancer 2019, 19, 333. [CrossRef] [PubMed]

79. Yuan, F.; Wang, W.; Cheng, H. Co-expression network analysis of gene expression profiles of HER2+ breast cancer-associated brain metastasis. Oncol. Lett. 2018, 16, 7008-7019. [CrossRef] [PubMed]

80. Brenton, J.D.; Carey, L.A.; Ahmed, A.A.; Caldas, C. Molecular classification and molecular forecasting of breast cancer: Ready for clinical application? J. Clin. Oncol. 2005, 23, 7350-7360. [CrossRef]

81. Berns, K.; Horlings, H.M.; Hennessy, B.T.; Madiredjo, M.; Hijmans, E.M.; Beelen, K.; Linn, S.C.; Gonzalez-Angulo, A.M.; Stemke-Hale, K.; Hauptmann, M.; et al. A functional genetic approach identifies the pi3k pathway as a major determinant of trastuzumab resistance in breast cancer. Cancer Cell 2007, 12, 395-402. [CrossRef] [PubMed] 
82. De Oliveira Taveira, M.; Nabavi, S.; Wang, Y.; Tonellato, P.; Esteva, F.J.; Cantley, L.C.; Wulf, G.M. Genomic characteristics of trastuzumab-resistant HER2-positive metastatic breast cancer. J. Cancer Res. Clin. Oncol. 2017, 143, 1255-1262. [CrossRef] [PubMed]

83. Nagata, Y.; Lan, K.-H.; Zhou, X.; Tan, M.; Esteva, F.J.; Sahin, A.A.; Klos, K.S.; Li, P.; Monia, B.P.; Nguyen, N.T.; et al. Pten activation contributes to tumor inhibition by trastuzumab, and loss of pten predicts trastuzumab resistance in patients. Cancer Cell 2004, 6, 117-127. [CrossRef]

84. Morrow, P.K.; Wulf, G.M.; Ensor, J.; Booser, D.J.; Moore, J.A.; Flores, P.R.; Xiong, Y.; Zhang, S.; Krop, I.E.; Winer, E.P.; et al. Phase i/ii study of trastuzumab in combination with everolimus (rad001) in patients with HER2-overexpressing metastatic breast cancer who progressed on trastuzumab-based therapy. J. Clin. Oncol. 2011, 29, 3126-3132. [CrossRef]

85. Omarini, C.; Bettelli, S.; Caprera, C.; Manfredini, S.; Barbolini, M.; Moscetti, L.; Isca, C.; Toss, A.; Barbieri, E.; Cortesi, L.; et al. Differential molecular pathways expression in HER2 positive early breast cancer according to hormone receptor status. J. Cancer Res. Clin. Oncol. 2019, 145, 821-828. [CrossRef]

86. Lee, R.C.; Feinbaum, R.L.; Ambros, V. The c. Elegans heterochronic gene lin-4 encodes small rnas with antisense complementarity to lin-14. Cell 1993, 75, 843-854. [CrossRef]

87. Hamam, R.; Hamam, D.; Alsaleh, K.A.; Kassem, M.; Zaher, W.; Alfayez, M.; Aldahmash, A.; Alajez, N.M. Circulating microRNAs in breast cancer: Novel diagnostic and prognostic biomarkers. Cell Death Dis. 2017, 8, e3045. [CrossRef]

88. Mendell, J.T.; Olson, E.N. MicroRNAs in stress signaling and human disease. Cell 2012, 148, 1172-1187. [CrossRef]

89. Song, S.; Ajani, J.A. The role of microRNAs in cancers of the upper gastrointestinal tract. Nature Rev. Gastroenterol. Hepatol. 2013, 10, 109-118. [CrossRef]

90. Svoronos, A.A.; Engelman, D.M.; Slack, F.J. Oncomir or tumor suppressor? The duplicity of microRNAs in cancer. Cancer Res. 2016, 76, 3666-3670. [CrossRef]

91. Kahraman, M.; Röske, A.; Laufer, T.; Fehlmann, T.; Backes, C.; Kern, F.; Kohlhaas, J.; Schrörs, H.; Saiz, A.; Zabler, C.; et al. MicroRNA in diagnosis and therapy monitoring of early-stage triple-negative breast cancer. Sci. Rep. 2018, 8, 11584. [CrossRef]

92. Van Schooneveld, E.; Wouters, M.C.; Van der Auwera, I.; Peeters, D.J.; Wildiers, H.; Van Dam, P.A.; Vergote, I.; Vermeulen, P.B.; Dirix, L.Y.; Van Laere, S.J. Expression profiling of cancerous and normal breast tissues identifies microRNAs that are differentially expressed in serum from patients with (metastatic) breast cancer and healthy volunteers. Breast Cancer Res. 2012, 14, R34. [CrossRef]

93. Dave, V.P.; Ngo, T.A.; Pernestig, A.-K.; Tilevik, D.; Kant, K.; Nguyen, T.; Wolff, A.; Bang, D.D. MicroRNA amplification and detection technologies: Opportunities and challenges for point of care diagnostics. Lab. Invest. 2019, 99, 452-469. [CrossRef]

94. Kost, G.J.; Tran, N.K.; Louie, R.F. Point-of-care testing: Principles, practice, and critical-emergency-disaster medicine. In Encyclopedia of Analytical Chemistry; Meyers, R.A., Ed.; John Wiley \& Sons, Ltd.: New York, NY, USA, 2008. [CrossRef]

95. Huang, T.; Yang, J.; Liu, G.; Jin, W.; Liu, Z.; Zhao, S.; Yao, M. Quantification of mature microRNAs using pincer probes and real-time pcr amplification. PLoS ONE 2015, 10, e120160. [CrossRef] [PubMed]

96. Vedarethinam, I.; Shah, P.; Dimaki, M.; Tumer, Z.; Tommerup, N.; Svendsen, W.E. Metaphase fish on a chip: Miniaturized microfluidic device for fluorescence in situ hybridization. Sensors 2010, 10, 9831-9846. [CrossRef]

97. Whitesides, G.M. The origins and the future of microfluidics. Nature 2006, 442, 368-373. [CrossRef] [PubMed]

98. Zhou, Y.; Wang, M.; Yang, Z.; Lu, L.; Yin, H.; Ai, S. Electrochemical biosensor for microRNA detection based on hybridization protection against nuclease s1 digestion. J. Solid State Electrochem. 2016, 20, 413-419. [CrossRef]

99. Kian, R.; Moradi, S.; Ghorbian, S. Role of components of microRNA machinery in carcinogenesis. Exp. Oncol. 2018, 40, 2-9. [CrossRef]

100. Van Schooneveld, E.; Wildiers, H.; Vergote, I.; Vermeulen, P.B.; Dirix, L.Y.; Van Laere, S.J. Dysregulation of microRNAs in breast cancer and their potential role as prognostic and predictive biomarkers in patient management. Breast Cancer Res. 2015, 17, 21. [CrossRef]

101. Inns, J.; James, V. Circulating microRNAs for the prediction of metastasis in breast cancer patients diagnosed with early stage disease. Breast 2015, 24, 364-369. [CrossRef] [PubMed] 
102. Serpico, D.; Molino, L.; Di Cosimo, S. MicroRNAs in breast cancer development and treatment. Cancer Treat. Rev. 2014, 40, 595-604. [CrossRef]

103. Zhu, W.; Qin, W.; Atasoy, U.; Sauter, E.R. Circulating microRNAs in breast cancer and healthy subjects. BMC Res. Notes 2009, 2, 89. [CrossRef]

104. Freiesleben, S.; Hecker, M.; Zettl, U.K.; Fuellen, G.; Taher, L. Analysis of microRNA and gene expression profiles in multiple sclerosis: Integrating interaction data to uncover regulatory mechanisms. Sci. Rep. 2016, 6, 34512. [CrossRef]

105. Khalighfard, S.; Alizadeh, A.M.; Irani, S.; Omranipour, R. Plasma Mir-21, Mir-155, Mir-10b, and Let-7a as the potential biomarkers for the monitoring of breast cancer patients. Sci. Rep. 2018, 8, 17981. [CrossRef]

106. Fkih M'hamed, I.; Privat, M.; Trimeche, M.; Penault-Llorca, F.; Bignon, Y.-J.; Kenani, A. Mir-10b, Mir-26a, Mir-146a and Mir-153 expression in triple negative vs. non triple negative breast cancer: Potential biomarkers. Pathol. Oncol. Res. 2017, 23, 815-827. [CrossRef] [PubMed]

107. Tashkandi, H.; Shah, N.; Patel, Y.; Chen, H. Identification of new miRNA biomarkers associated with HER2-positive breast cancers. Oncoscience 2015, 2, 924-929.

108. Uhlmann, S.; Mannsperger, H.; Zhang, J.D.; Horvat, E.-Á.; Schmidt, C.; Küblbeck, M.; Henjes, F.; Ward, A.; Tschulena, U.; Zweig, K.; et al. Global microRNA level regulation of egfr-driven cell-cycle protein network in breast cancer. Mol. Syst. Biol. 2012, 8, 570. [CrossRef] [PubMed]

109. Leivonen, S.-K.; Sahlberg, K.K.; Mäkelä, R.; Due, E.U.; Kallioniemi, O.; Børresen-Dale, A.-L.; Perälä, M. High-throughput screens identify microRNAs essential for HER2 positive breast cancer cell growth. Mol. Oncol. 2014, 8, 93-104. [CrossRef]

110. Mattie, M.D.; Benz, C.C.; Bowers, J.; Sensinger, K.; Wong, L.; Scott, G.K.; Fedele, V.; Ginzinger, D.; Getts, R.; Haqq, C. Optimized high-throughput microRNA expression profiling provides novel biomarker assessment of clinical prostate and breast cancer biopsies. Mol. Cancer 2006, 5, 24. [CrossRef]

111. Lowery, A.J.; Miller, N.; Devaney, A.; McNeill, R.E.; Davoren, P.A.; Lemetre, C.; Benes, V.; Schmidt, S.; Blake, J.; Ball, G.; et al. MicroRNA signatures predict oestrogen receptor, progesterone receptor and HER2/NEU receptor status in breast cancer. Breast cancer Res. 2009, 11, R27. [CrossRef]

112. Grelier, G.; Voirin, N.; Ay, A.S.; Cox, D.G.; Chabaud, S.; Treilleux, I.; Léon-Goddard, S.; Rimokh, R.; Mikaelian, I.; Venoux, C.; et al. Prognostic value of dicer expression in human breast cancers and association with the mesenchymal phenotype. Br. J. Cancer 2009, 101, 673-683. [CrossRef] [PubMed]

113. Dedes, K.J.; Natrajan, R.; Lambros, M.B.; Geyer, F.C.; Lopez-Garcia, M.A.; Savage, K.; Jones, R.L.; Reis-Filho, J.S. Down-regulation of the miRNA master regulators drosha and dicer is associated with specific subgroups of breast cancer. Eur. J. Cancer 2011, 47, 138-150. [CrossRef] [PubMed]

114. Cava, C.; Bertoli, G.; Ripamonti, M.; Mauri, G.; Zoppis, I.; Della Rosa, P.A.; Gilardi, M.C.; Castiglioni, I. Integration of mrna expression profile, copy number alterations, and microRNA expression levels in breast cancer to improve grade definition. PLoS ONE 2014, 9, e97681. [CrossRef]

115. Du, F.; Yuan, P.; Zhao, Z.T.; Yang, Z.; Wang, T.; Zhao, J.D.; Luo, Y.; Ma, F.; Wang, J.Y.; Fan, Y.; et al. A miRNA-based signature predicts development of disease recurrence in HER2 positive breast cancer after adjuvant trastuzumab-based treatment. Sci. Rep. 2016, 6, 33825. [CrossRef]

116. Yin, Q.-W.; Sun, X.-F.; Yang, G.-T.; Li, X.-B.; Wu, M.-S.; Zhao, J. Increased expression of microRNA-150 is associated with poor prognosis in non-small cell lung cancer. Int. J. Clin. Exp. Pathol. 2015, 8, 842-846.

117. Sugita, B.M.; Zabala, Y.; Fonseca, A.; Almeida, R.; Gusev, Y.; Boca, S.; Cavalli, I.J.; Ribeiro, E.M.; Cavalli, L.R. Abstract 3431: The oncogenic role of Mir-150-5p in triple-negative breast cancer. Cancer Res. 2017, 77, 3431. [CrossRef]

118. Persson, H.; Kvist, A.; Rego, N.; Staaf, J.; Vallon-Christersson, J.; Luts, L.; Loman, N.; Jonsson, G.; Naya, H.; Hoglund, M.; et al. Identification of new microRNAs in paired normal and tumor breast tissue suggests a dual role for the ERBB2/HER2 gene. Cancer Res. 2011, 71, 78-86. [CrossRef]

119. Brow, D.A.; Guthrie, C. Spliceosomal rna u6 is remarkably conserved from yeast to mammals. Nature 1988, 334, 213-218. [CrossRef]

120. Zohreh, R.; Ahmadreza, S.; Mohammad, K.-T.D.; Kazem, D. Involvement of the dysregulation of Mir-23b-3p, Mir-195-5p, Mir-656-5p, and Mir-340-5p in trastuzumab resistance of HER2-positive breast cancer cells and system biology approach to predict their targets involved in resistance. DNA Cell Biol. 2019, 38, 184-192.

121. Wang, B.; Zhang, Q. The expression and clinical significance of circulating microRNA-21 in serum of five solid tumors. J. Cancer Res. Clin. Oncol. 2012, 138, 1659-1666. [CrossRef] 
122. Han, J.-G.; Jiang, Y.-D.; Zhang, C.-H.; Yang, Y.-M.; Pang, D.; Song, Y.-N.; Zhang, G.-Q. A novel panel of serum Mir-21/Mir-155/Mir-365 as a potential diagnostic biomarker for breast cancer. Ann. Surg. Treat. Res. 2017, 92, 55-66. [CrossRef]

123. Fujita, S.; Ito, T.; Mizutani, T.; Minoguchi, S.; Yamamichi, N.; Sakurai, K.; Iba, H. Mir-21 gene expression triggered by ap-1 is sustained through a double-negative feedback mechanism. J. Mol. Biol. 2008, 378, 492-504. [CrossRef] [PubMed]

124. Pan, X.; Wang, Z.X.; Wang, R. MicroRNA-21: A novel therapeutic target in human cancer. Cancer Biol. Ther. 2010, 10, 1224-1232. [CrossRef]

125. Huang, T.-H.; Wu, F.; Loeb, G.B.; Hsu, R.; Heidersbach, A.; Brincat, A.; Horiuchi, D.; Lebbink, R.J.; Mo, Y.-Y.; Goga, A.; et al. Up-regulation of Mir-21 by HER2/NEU signaling promotes cell invasion. J. Biol. Chem. 2009, 284, 18515-18524. [CrossRef] [PubMed]

126. Frankel, L.B.; Christoffersen, N.R.; Jacobsen, A.; Lindow, M.; Krogh, A.; Lund, A.H. Programmed cell death 4 (pdcd4) is an important functional target of the microRNA Mir-21 in breast cancer cells. J. Biol. Chem. 2008, 283, 1026-1033. [CrossRef] [PubMed]

127. Zhu, S.; Si, M.-L.; Wu, H.; Mo, Y.-Y. MicroRNA-21 targets the tumor suppressor gene tropomyosin 1 (tpm1). J. Biol. Chem. 2007, 282, 14328-14336. [CrossRef]

128. Asangani, I.A.; Rasheed, S.A.K.; Nikolova, D.A.; Leupold, J.H.; Colburn, N.H.; Post, S.; Allgayer, H. MicroRNA-21 (Mir-21) post-transcriptionally downregulates tumor suppressor pdcd4 and stimulates invasion, intravasation and metastasis in colorectal cancer. Oncogene 2007, 27, 2128-2136. [CrossRef]

129. Göke, R.; Barth, P.; Schmidt, A.; Samans, B.; Lankat-Buttgereit, B. Programmed cell death protein 4 suppresses cdk1/cdc2 via induction of p21waf1/cip1. Am. J. Physiol. Cell Physiol. 2004, 287, C1541. [CrossRef]

130. De Mattos-Arruda, L.; Bottai, G.; Nuciforo, P.G.; Di Tommaso, L.; Giovannetti, E.; Peg, V.; Losurdo, A.; Pérez-Garcia, J.; Masci, G.; Corsi, F.; et al. MicroRNA-21 links epithelial-to-mesenchymal transition and inflammatory signals to confer resistance to neoadjuvant trastuzumab and chemotherapy in HER2-positive breast cancer patients. Oncotarget 2015, 6, 37269-37280. [CrossRef]

131. Davis, B.N.; Hilyard, A.C.; Lagna, G.; Hata, A. Smad proteins control drosha-mediated microRNA maturation. Nature 2008, 454, 56-61. [CrossRef] [PubMed]

132. Dai, X.; Fang, M.; Li, S.; Yan, Y.; Zhong, Y.; Du, B. Mir-21 is involved in transforming growth factor $\beta 1$-induced chemoresistance and invasion by targeting pten in breast cancer. Oncol. Lett. 2017, 14, 6929-6936. [CrossRef] [PubMed]

133. Hatley, M.E.; Patrick, D.M.; Garcia, M.R.; Richardson, J.A.; Bassel-Duby, R.; van Rooij, E.; Olson, E.N. Modulation of k-ras-dependent lung tumorigenesis by microRNA-21. Cancer Cell 2010, 18, 282-293. [CrossRef]

134. Fong, S.; Itahana, Y.; Sumida, T.; Singh, J.; Coppe, J.-P.; Liu, Y.; Richards, P.C.; Bennington, J.L.; Lee, N.M.; Debs, R.J.; et al. Id-1 as a molecular target in therapy for breast cancer cell invasion and metastasis. Proc. Natl. Acad. Sci. USA 2003, 100, 13543-13548. [CrossRef]

135. Migliaccio, A.; Piccolo, D.; Castoria, G.; Di Domenico, M.; Bilancio, A.; Lombardi, M.; Gong, W.; Beato, M.; Auricchio, F. Activation of the src/p21ras/erk pathway by progesterone receptor via cross-talk with estrogen receptor. EMBO J. 1998, 17, 2008-2018. [CrossRef]

136. Quinn, J.A.; Bland, K.I.; Filardo, E.J.; Frackelton, A.R., Jr. Estrogen-induced activation of erk-1 and erk-2 requires the g protein-coupled receptor homolog, gpr30, and occurs via trans-activation of the epidermal growth factor receptor through release of hb-egf. Mol. Endocrinol. 2000, 14, 1649-1660.

137. Niu, J.; Shi, Y.; Tan, G.; Yang, C.H.; Fan, M.; Pfeffer, L.M.; Wu, Z.-H. DNA damage induces nf-kb-dependent microRNA-21 up-regulation and promotes breast cancer cell invasion. J. Biol. Chem. 2012, 287, 21783-21795. [CrossRef]

138. Gong, C.; Yao, Y.; Wang, Y.; Liu, B.; Wu, W.; Chen, J.; Su, F.; Yao, H.; Song, E. Up-regulation of Mir-21 mediates resistance to trastuzumab therapy for breast cancer. J. biol. Chem. 2011, 286, 19127-19137. [CrossRef]

139. Huang, X.; Le, Q.-T.; Giaccia, A.J. Mir-210-micromanager of the hypoxia pathway. Trends Mol. Med. 2010, 16, 230-237. [CrossRef]

140. Liu, D.; Xia, H.; Wang, F.; Chen, C.; Long, J. MicroRNA-210 interacts with fbxo31 to regulate cancer proliferation cell cycle and migration in human breast cancer. OncoTargets Ther. 2016, 9, 5245-5255.

141. Graveel, C.; Calderone, H.; Westerhuis, J.; Winn, M.; Sempere, L. Critical analysis of the potential for microRNA biomarkers in breast cancer management. Breast Cancer (Dove Med. Press) 2015, 7, 59-79. 
142. Volinia, S.; Galasso, M.; Sana, M.E.; Wise, T.F.; Palatini, J.; Huebner, K.; Croce, C.M. Breast cancer signatures for invasiveness and prognosis defined by deep sequencing of microRNA. Proc. Natl. Acad. Sci. USA 2012, 109, 3024-3029. [CrossRef]

143. Jung, E.-J.; Santarpia, L.; Kim, J.; Esteva, F.J.; Moretti, E.; Buzdar, A.U.; Di Leo, A.; Le, X.-F.; Bast, R.C., Jr.; Park, S.-T.; et al. Plasma microRNA 210 levels correlate with sensitivity to trastuzumab and tumor presence in breast cancer patients. Cancer 2012, 118, 2603-2614. [CrossRef]

144. Patel, Y.; Shah, N.; Lee, J.S.; Markoutsa, E.; Jie, C.; Liu, S.; Botbyl, R.; Reisman, D.; Xu, P.; Chen, H. A novel double-negative feedback loop between Mir-489 and the HER2-shp2-mapk signaling axis regulates breast cancer cell proliferation and tumor growth. Oncotarget 2016, 7, 18295-18308. [CrossRef]

145. Kikkawa, N.; Hanazawa, T.; Fujimura, L.; Nohata, N.; Suzuki, H.; Chazono, H.; Sakurai, D.; Horiguchi, S.; Okamoto, Y.; Seki, N. Mir-489 is a tumour-suppressive miRNA target ptpn11 in hypopharyngeal squamous cell carcinoma (hscc). Br. J. Cancer 2010, 103, 877-884. [CrossRef] [PubMed]

146. Jiang, L.; He, D.; Yang, D.; Chen, Z.; Pan, Q.; Mao, A.; Cai, Y.; Li, X.; Xing, H.; Shi, M.; et al. Mir-489 regulates chemoresistance in breast cancer via epithelial mesenchymal transition pathway. FEBS Lett. 2014, 588, 2009-2015. [CrossRef] [PubMed]

147. Anfossi, S.; Giordano, A.; Gao, H.; Cohen, E.N.; Tin, S.; Wu, Q.; Garza, R.J.; Debeb, B.G.; Alvarez, R.H.; Valero, V.; et al. High serum Mir-19a levels are associated with inflammatory breast cancer and are predictive of favorable clinical outcome in patients with metastatic HER2+ inflammatory breast cancer. PLoS ONE 2014, 9, e83113. [CrossRef]

148. Cheung, T.H.; Quach, N.L.; Charville, G.W.; Liu, L.; Park, L.; Edalati, A.; Yoo, B.; Hoang, P.; Rando, T.A. Maintenance of muscle stem-cell quiescence by microRNA-489. Nature 2012, 482, 524-528. [CrossRef] [PubMed]

149. Pogribny, I.P.; Filkowski, J.N.; Tryndyak, V.P.; Golubov, A.; Shpyleva, S.I.; Kovalchuk, O. Alterations of microRNAs and their targets are associated with acquired resistance of mcf-7 breast cancer cells to cisplatin. Int. J. Cancer 2010, 127, 1785-1794. [CrossRef] [PubMed]

150. Zhang, J.; Yang, J.; Zhang, X.; Xu, J.; Sun, Y.; Zhang, P. MicroRNA-10b expression in breast cancer and its clinical association. PLoS ONE 2018, 13, e0192509. [CrossRef]

151. Hong, Y.; Liang, H.; Uzair ur, R.; Wang, Y.; Zhang, W.; Zhou, Y.; Chen, S.a.; Yu, M.; Cui, S.; Liu, M.; et al. Mir-96 promotes cell proliferation, migration and invasion by targeting ptpn9 in breast cancer. Sci. Rep. 2016, 6, 37421. [CrossRef] [PubMed]

152. Ng, E.K.O.; Li, R.; Shin, V.Y.; Siu, J.M.; Ma, E.S.K.; Kwong, A. MicroRNA-143 is downregulated in breast cancer and regulates DNA methyltransferases 3a in breast cancer cells. Tumor Biol. 2014, 35, 2591-2598. [CrossRef] [PubMed]

153. Zhang, L.; Chen, Y.; Wang, H.; Zheng, X.; Li, C.; Han, Z. Mir-376a inhibits breast cancer cell progression by targeting neuropilin-1 nr. OncoTargets Ther. 2018, 11, 5293-5302. [CrossRef] [PubMed]

154. Wang, S.; Li, H.; Wang, J.; Wang, D.; Yao, A.; Li, Q. Prognostic and biological significance of microRNA-127 expression in human breast cancer. Dis. Markers 2014, 2014, 401986. [CrossRef] [PubMed]

155. Chiang, C.-H.; Chu, P.-Y.; Hou, M.-F.; Hung, W.-C. Mir-182 promotes proliferation and invasion and elevates the hif- $1 \alpha$-vegf-a axis in breast cancer cells by targeting fbxw7. Am. J. Cancer Res. 2016, 6, 1785-1798. [PubMed]

156. Ye, X.; Bai, W.; Zhu, H.; Zhang, X.; Chen, Y.; Wang, L.; Yang, A.; Zhao, J.; Jia, L. Mir-221 promotes trastuzumab-resistance and metastasis in HER2-positive breast cancers by targeting pten. BMB Rep. 2014, 47, 268-273. [CrossRef]

157. Yang, F.; Li, Y.; Xu, L.; Zhu, Y.; Gao, H.; Zhen, L.; Fang, L. Mir-17 as a diagnostic biomarker regulates cell proliferation in breast cancer. OncoTargets Ther. 2017, 10, 543-550. [CrossRef] [PubMed]

158. Luo, L.; Cheng, J.; Yang, R.; Zhao, S.; Wang, T.; Chen, Y.; Chen, D.; Zhang, T.; Hong, S.; Wang, K. Decreased Mir-320 expression is associated with breast cancer progression, cell migration, and invasiveness via targeting aquaporin 1. Acta Biochim. Biophys. Sin. (Shanghai). 2018, 50, 473-480. [CrossRef] [PubMed]

159. Barbano, R.; Pasculli, B.; Rendina, M.; Fontana, A.; Fusilli, C.; Copetti, M.; Castellana, S.; Valori, V.M.; Morritti, M.; Graziano, P.; et al. Stepwise analysis of Mir9 loci identifies Mir-9-5p to be involved in oestrogen regulated pathways in breast cancer patients. Sci. Rep. 2017, 7, 45283. [CrossRef] [PubMed]

160. Gong, Y.; He, T.; Yang, L.; Yang, G.; Chen, Y.; Zhang, X. The role of Mir-100 in regulating apoptosis of breast cancer cells. Sci. Rep. 2015, 5, 11650. [CrossRef]

161. Wang, S.E.; Lin, R.-J. MicroRNA and HER2-overexpressing cancer. MicroRNA 2013, 2, 137-147. [CrossRef] 
162. Wee, E.J.H.; Peters, K.; Nair, S.S.; Hulf, T.; Stein, S.; Wagner, S.; Bailey, P.; Lee, S.Y.; Qu, W.J.; Brewster, B.; et al. Mapping the regulatory sequences controlling 93 breast cancer-associated miRNA genes leads to the identification of two functional promoters of the HSA-Mir-200b cluster, methylation of which is associated with metastasis or hormone receptor status in advanced breast cancer. Oncogene 2012, 31, 4182-4195.

163. Matamala, N.; Vargas, M.T.; González-Cámpora, R.; Miñambres, R.; Arias, J.I.; Menéndez, P.; Andrés-León, E.; Gómez-López, G.; Yanowsky, K.; Calvete-Candenas, J.; et al. Tumor microRNA expression profiling identifies circulating microRNAs for early breast cancer detection. Clin. Chem. 2015, 61, 1098-1106. [CrossRef]

164. Bertoli, G.; Cava, C.; Castiglioni, I. The potential of miRNAs for diagnosis, treatment and monitoring of breast cancer. Scand. J. Clin. Lab. Invest. Suppl. 2016, 245, S34-S39. [CrossRef] [PubMed]

165. Cuk, K.; Zucknick, M.; Madhavan, D.; Schott, S.; Golatta, M.; Heil, J.; Marmé, F.; Turchinovich, A.; Sinn, P.; Sohn, C.; et al. Plasma microRNA panel for minimally invasive detection of breast cancer. PLoS ONE 2013, 8, e76729. [CrossRef] [PubMed]

166. Antolín, S.; Calvo, L.; Blanco-Calvo, M.; Santiago, M.P.; Lorenzo-Patiño, M.J.; Haz-Conde, M.; Santamarina, I.; Figueroa, A.; Antón-Aparicio, L.M.; Valladares-Ayerbes, M. Circulating Mir-200c and Mir-141 and outcomes in patients with breast cancer. BMC Cancer 2015, 15, 297. [CrossRef]

167. Wang, P.-Y.; Gong, H.-T.; Li, B.-F.; Lv, C.-L.; Wang, H.-T.; Zhou, H.-H.; Li, X.-X.; Xie, S.-Y.; Jiang, B.-F. Higher expression of circulating Mir-182 as a novel biomarker for breast cancer. Oncol. Lett. 2013, 6, 1681-1686. [CrossRef] [PubMed]

168. Mangolini, A.; Ferracin, M.; Zanzi, M.V.; Saccenti, E.; Ebnaof, S.O.; Poma, V.V.; Sanz, J.M.; Passaro, A.; Pedriali, M.; Frassoldati, A.; et al. Diagnostic and prognostic microRNAs in the serum of breast cancer patients measured by droplet digital PCR. Biomarker Res. 2015, 3, 12. [CrossRef] [PubMed]

169. Ward, A.; Balwierz, A.; Zhang, J.D.; Küblbeck, M.; Pawitan, Y.; Hielscher, T.; Wiemann, S.; Sahin, Ö. Re-expression of microRNA-375 reverses both tamoxifen resistance and accompanying emt-like properties in breast cancer. Oncogene 2012, 32, 1173-1182. [CrossRef]

170. Young, J.; Kawaguchi, T.; Yan, L.; Qi, Q.; Liu, S.; Takabe, K. Tamoxifen sensitivity-related microRNA-342 is a useful biomarker for breast cancer survival. Oncotarget 2017, 8, 99978-99989. [CrossRef] [PubMed]

171. Li, J.; Lu, M.; Jin, J.; Lu, X.; Xu, T.; Jin, S. Mir-449a suppresses tamoxifen resistance in human breast cancer cells by targeting adam22. Cell. Physiol. Biochem. 2018, 50, 136-149. [CrossRef] [PubMed]

172. Roskoski, R. The Erbb/HER family of protein-tyrosine kinases and cancer. Pharmacol. Res. 2014, 79, 34-74. [CrossRef]

173. Noyan, S.; Gurdal, H.; Gur Dedeoglu, B. Involvement of Mir-770-5p in trastuzumab response in HER2 positive breast cancer cells. PLoS ONE 2019, 14, e215894. [CrossRef]

174. Chen, G.; He, M.; Yin, Y.; Yan, T.; Cheng, W.; Huang, Z.; Zhang, L.; Zhang, H.; Liu, P.; Zhu, W.; et al. Mir-1296-5p decreases erbb2 expression to inhibit the cell proliferation in erbb2-positive breast cancer. Cancer Cell Int. 2017, 17, 95. [CrossRef]

175. Yang, F.; Fu, Z.; Yang, M.; Sun, C.; Li, Y.; Chu, J.; Zhang, Y.; Li, W.; Huang, X.; Li, J.; et al. Expression pattern of microRNAs related with response to trastuzumab in breast cancer. J. Cell. Physiol. 2019. [CrossRef] [PubMed]

176. Han, G.; Qiu, N.; Luo, K.; Liang, H.; Li, H. Downregulation of miroRNA-141 mediates acquired resistance to trastuzumab and is associated with poor outcome in breast cancer by upregulating the expression of ERBB4. J. Cell. Biochem. 2019. [CrossRef]

177. Liu, Y.; Xu, J.; Choi, H.H.; Han, C.; Fang, Y.; Li, Y.; Van der Jeught, K.; Xu, H.; Zhang, L.; Frieden, M.; et al. Targeting 17q23 amplicon to overcome the resistance to anti-HER2 therapy in HER2+ breast cancer. Nat. Commun. 2018, 9, 4718. [CrossRef] [PubMed]

178. Arroyo, J.D.; Chevillet, J.R.; Kroh, E.M.; Ruf, I.K.; Pritchard, C.C.; Gibson, D.F.; Mitchell, P.S.; Bennett, C.F.; Pogosova-Agadjanyan, E.L.; Stirewalt, D.L.; et al. Argonaute2 complexes carry a population of circulating microRNAs independent of vesicles in human plasma. Proc. Natl. Acad. Sci. USA 2011, 108, 5003-5008. [CrossRef] [PubMed]

179. Gallo, A.; Tandon, M.; Alevizos, I.; Illei, G.G. The majority of microRNAs detectable in serum and saliva is concentrated in exosomes. PLoS ONE 2012, 7, e30679. [CrossRef]

180. Hessvik, N.P.; Sandvig, K.; Llorente, A. Exosomal miRNAs as biomarkers for prostate cancer. Front. Genet. 2013, 4, 36. [CrossRef] 
181. Ogata-Kawata, H.; Izumiya, M.; Kurioka, D.; Honma, Y.; Yamada, Y.; Furuta, K.; Gunji, T.; Ohta, H.; Okamoto, H.; Sonoda, H.; et al. Circulating exosomal microRNAs as biomarkers of colon cancer. PLoS ONE 2014, 9, e92921. [CrossRef]

182. Skog, J.; Würdinger, T.; van Rijn, S.; Meijer, D.H.; Gainche, L.; Sena-Esteves, M.; Curry, W.T., Jr.; Carter, B.S.; Krichevsky, A.M.; Breakefield, X.O. Glioblastoma microvesicles transport RNA and proteins that promote tumour growth and provide diagnostic biomarkers. Nat. Cell Biol. 2008, 10, 1470-1476. [CrossRef]

183. Sueta, A.; Yamamoto, Y.; Tomiguchi, M.; Takeshita, T.; Yamamoto-Ibusuki, M.; Iwase, H. Differential expression of exosomal miRNAs between breast cancer patients with and without recurrence. Oncotarget 2017, 8, 69934-69944. [CrossRef]

184. Eichelser, C.; Stückrath, I.; Müller, V.; Milde-Langosch, K.; Wikman, H.; Pantel, K.; Schwarzenbach, H. Increased serum levels of circulating exosomal microRNA-373 in receptor-negative breast cancer patients. Oncotarget 2014, 5, 9650-9663. [CrossRef]

185. Sachdeva, M.; Wu, H.; Ru, P.; Hwang, L.; Trieu, V.; Mo, Y.Y. MicroRNA-101-mediated akt activation and estrogen-independent growth. Oncogene 2010, 30, 822-831. [CrossRef] [PubMed]

186. Amancio, C.; Carmen, B.-A.; Oliver, R.; Wolfgang, L.; Juan, F.M.L. The pten/pi3k/akt signalling pathway in cancer, therapeutic implications. Current Cancer Drug Targets 2008, 8, 187-198.

(C) 2019 by the authors. Licensee MDPI, Basel, Switzerland. This article is an open access article distributed under the terms and conditions of the Creative Commons Attribution (CC BY) license (http://creativecommons.org/licenses/by/4.0/). 